\title{
Hydrogen Peroxide Signaling in Plant Development and Abiotic Responses: Crosstalk with Nitric Oxide and Calcium
}

\author{
Lijuan Niu and Weibiao Liao* \\ Department of Ornamental Horticulture, College of Horticulture, Gansu Agricultural University, Lanzhou, China
}

Hydrogen peroxide $\left(\mathrm{H}_{2} \mathrm{O}_{2}\right)$, as a reactive oxygen species, is widely generated in many biological systems. It has been considered as an important signaling molecule that mediates various physiological and biochemical processes in plants. Normal metabolism in plant cells results in $\mathrm{H}_{2} \mathrm{O}_{2}$ generation, from a variety of sources. Also, it is now clear that nitric oxide $(\mathrm{NO})$ and calcium $\left(\mathrm{Ca}^{2+}\right)$ function as signaling molecules in plants. Both $\mathrm{H}_{2} \mathrm{O}_{2}$ and $\mathrm{NO}$ are involved in plant development and abiotic responses. A wide range of evidences suggest that $\mathrm{NO}$ could be generated under similar stress conditions and with similar kinetics as $\mathrm{H}_{2} \mathrm{O}_{2}$. The interplay between $\mathrm{H}_{2} \mathrm{O}_{2}$ and $\mathrm{NO}$ has important functional implications to modulate transduction processes in plants. Moreover, close interaction also exists between $\mathrm{H}_{2} \mathrm{O}_{2}$ and $\mathrm{Ca}^{2+}$ in response to development and abiotic stresses in plants. Cellular responses to $\mathrm{H}_{2} \mathrm{O}_{2}$ and $\mathrm{Ca}^{2+}$ signaling systems are complex. There is quite a bit of interaction between $\mathrm{H}_{2} \mathrm{O}_{2}$ and $\mathrm{Ca}^{2+}$ signaling in responses to several stimuli. This review aims to introduce these evidences in our understanding of the crosstalk among $\mathrm{H}_{2} \mathrm{O}_{2}$, NO, and $\mathrm{Ca}^{2+}$ signaling which regulates plant growth and development, and other cellular and physiological responses to abiotic stresses.

Keywords: hydrogen peroxide $\left(\mathrm{H}_{2} \mathrm{O}_{2}\right)$, nitric oxide (NO), calcium $\left(\mathrm{Ca}^{2+}\right)$, signal molecule, crosstalk

\section{INTRODUCTION}

Hydrogen peroxide $\left(\mathrm{H}_{2} \mathrm{O}_{2}\right)$, a form of reactive oxygen species, is regarded as a common cellular metabolite. $\mathrm{H}_{2} \mathrm{O}_{2}$ is continually synthesized through various sources including enzyme and nonenzyme pathways in plants. To date, it has become accepted that $\mathrm{H}_{2} \mathrm{O}_{2}$ plays important roles in plant developmental and physiological processes including seed germination (Barba-Espín et al., 2011), programmed cell death (PCD; Cheng et al., 2015; Vavilala et al., 2015), senescence (Liao et al., 2012b), flowering (Liu et al., 2013), root system development (Liao et al., 2009; Ma et al., 2014; Hernández-Barrera et al., 2015), stomatal aperture regulation (Ge et al., 2015) and many others. It is now clear that $\mathrm{H}_{2} \mathrm{O}_{2}$ functions as a signaling molecule which may respond to various stimuli in plant cells. These results suggest that $\mathrm{H}_{2} \mathrm{O}_{2}$ may be involved in cellular signaling transduction pathways and gene expression modulations in plants.

Nitric oxide (NO), as a small signaling molecule, appears to be involved in plant developmental and physiological processes such as seed germination (Wang et al., 2015), ripening and senescence (Shi Y. et al., 2015) as well as stomatal closure (Shi K. et al., 2015) and pollen tube growth (Wang et al., 2009). Meanwhile, NO signaling may have a vital role in the disease resistance 
(Kovacs et al., 2015) and response to abiotic stresses such as cold (Fan et al., 2015), salt (Liu W. et al., 2015) and drought (Shan et al., 2015). Calcium ion $\left(\mathrm{Ca}^{2+}\right)$ signaling is also a core regulator of plant physiological process and stress adaption such as cell polarity regulation (Zhou et al., 2014), leaf de-etiolation (Huang et al., 2012), stomatal closure (Zou et al., 2015). Additionally, $\mathrm{Ca}^{2+}$ signaling is also involved in various responses to abiotic stimuli, including light (Hu et al., 2015) and heavy metal (Li et al., 2016).

A large amount of research show that $\mathrm{H}_{2} \mathrm{O}_{2}, \mathrm{NO}$ and $\mathrm{Ca}^{2+}$ as signaling are involved in plant growth and development as well as response to abiotic stresses. In this review, we focus on $\mathrm{H}_{2} \mathrm{O}_{2}$ signaling activities and its cross-talk with $\mathrm{Ca}^{2+}$ and $\mathrm{NO}$ in plants.

\section{$\mathrm{H}_{2} \mathrm{O}_{2}$ HOMEOSTASIS \\ $\mathrm{H}_{2} \mathrm{O}_{2}$ Generation}

$\mathrm{H}_{2} \mathrm{O}_{2}$ is a byproduct of aerobic metabolism in plants (Mittler, 2002). Figure 1 shows that $\mathrm{H}_{2} \mathrm{O}_{2}$ in plants can be synthesized either enzymatically or non-enzymatically. There are numerous routes of $\mathrm{H}_{2} \mathrm{O}_{2}$ production in plant cells, such as photorespiration, electron transport chains (ETC), and redox reaction.

There is evidence for $\mathrm{H}_{2} \mathrm{O}_{2}$ production in plants through several enzymes includingcell wall peroxidases (Francoz et al., 2015), oxalate ( $\mathrm{Hu}$ et al., 2003), amine oxidases and flavincontaining enzymes (Cona et al., 2006; Figure 1). Moreover, nicotinamide adenine dinucleotide phosphate (NADPH) oxidases may also increase $\mathrm{H}_{2} \mathrm{O}_{2}$ level through generating superoxide which could be converted to $\mathrm{H}_{2} \mathrm{O}_{2}$ by superoxide dismutases (SOD; Grivennikova and Vinogradov, 2013; Brewer et al., 2015). Remans et al. (2010) observed that ROS accumulation, especially $\mathrm{H}_{2} \mathrm{O}_{2}$ formation, is mostly related with the stimulation of NADPH oxidase in plants under heavy metal stresses. Moreover, $\mathrm{H}_{2} \mathrm{O}_{2}$ produced by NADPH oxidases may significantly increase proline accumulation in Arabidopsis thaliana under salt or mannitol stress (Ben Rejeb et al., 2015). Additionally, some other oxidases such as glucose oxidases, glycolate oxidases (Chang and Tang, 2014), and sulfite oxidases (Brychkova et al., 2012) may oxidize their own substrates to produce $\mathrm{H}_{2} \mathrm{O}_{2}$ (Figure 1).

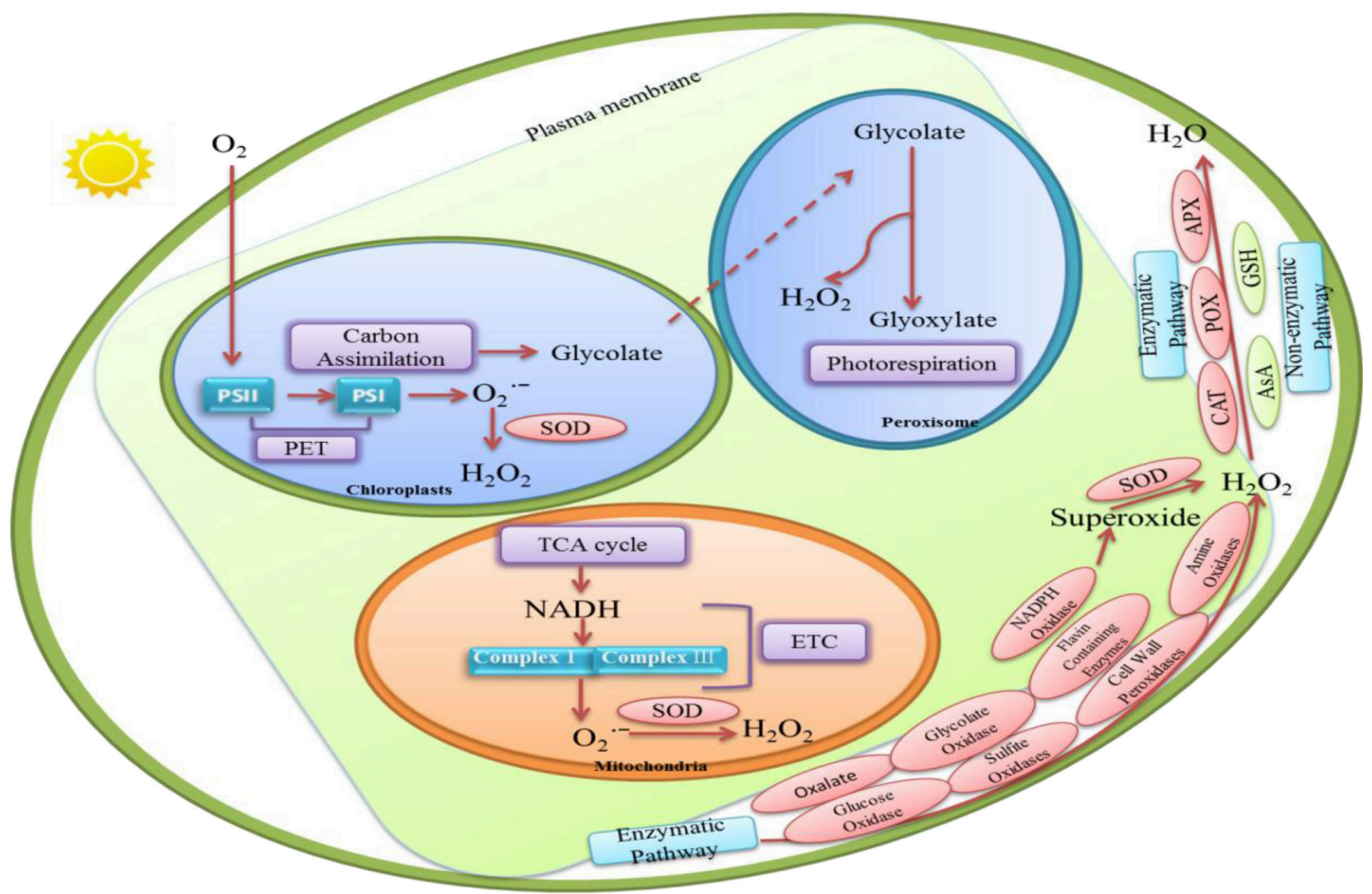

FIGURE 1 | The various routes of hydrogen perioxide $\left(\mathrm{H}_{2} \mathrm{O}_{2}\right)$ production and $\mathrm{H}_{2} \mathrm{O}_{2}$ removal in plant cells. Enzymatic production of $\mathrm{H}_{2} \mathrm{O}_{2}$ in plants requires several enzymes including cell wall peroxidases (Francoz et al., 2015), oxalate (Hu et al., 2003), amine oxidases and flavin-containing enzymes (Cona et al., 2006), glucose oxidases, glycolate oxidases (Chang and Tang, 2014), and sulfite oxidases (Brychkova et al., 2012). In these enzymes, some of them may convert $\mathrm{O}_{2}^{-}$to $\mathrm{H}_{2} \mathrm{O}_{2}$ and $\mathrm{O}_{2}$. And others may oxidize their each substrates to generate $\mathrm{H}_{2} \mathrm{O}_{2}$ in biocatalysis processes. Several non-enzymatic reactions are also known to produce $\mathrm{H}_{2} \mathrm{O}_{2}$. In peroxisome, $\mathrm{H}_{2} \mathrm{O}_{2}$ synthesis is associated with glycolate oxidation during photosynthetic carbon oxidation cycle (Foyer and Noctor, 2003). In chloroplasts, $\mathrm{H}_{2} \mathrm{O}_{2}$ production can be produced by the reduction of $\mathrm{O}_{2}^{-}$by photosynthetic electron transport (PET) chain. $\mathrm{H}_{2} \mathrm{O}_{2}$ in chloroplast also may be detected at the manganese-containing, oxygen evolving complex which is the donor site of photosystem II. Moreover, $\mathrm{H}_{2} \mathrm{O}_{2}$ could be generated in mitochondria through aerobic respiration because $\mathrm{O}_{2}^{-}$is produced from complexes I and III in the electron transport chain. $\mathrm{H}_{2} \mathrm{O}_{2}$-scavenging enzymes include catalase (CAT; Willekens et al., 1997), peroxidase (POX; Fan and Huang, 2012), ascorbate peroxidase (APX) and glutathione reductase (GR; Jahan and Anis, 2014). In non-enzymatic pathway, Ascorbate (AsA) and glutathione (GSH) are responsible for decreasing $\mathrm{H}_{2} \mathrm{O}_{2}$ level (Kapoor et al., 2015). 
Several non-enzymatic reactions are also known to produce $\mathrm{H}_{2} \mathrm{O}_{2}$. For example, many reactions involved in photosynthesis and respiration are responsible for $\mathrm{H}_{2} \mathrm{O}_{2}$ production. It is generated continually via electron transport reactions both in mitochondria and chloroplasts (Figure 1).

\section{Peroxisomes}

Peroxisome is considered to be the site of photorespiration in plant cell, which needs light-dependent uptake of $\mathrm{O}_{2}$ and releases $\mathrm{CO}_{2}$ accompanying with the generation of $\mathrm{H}_{2} \mathrm{O}_{2}$. It is suggested that $\mathrm{H}_{2} \mathrm{O}_{2}$ synthesis is associated with the oxidation of glycolate during the photosynthetic carbon oxidation cycle (Foyer and Noctor, 2003; Figure 1).

\section{Chloroplasts}

Chloroplast is the source of photosynthesis in plants. Chloroplasts are the crucial sites for $\mathrm{H}_{2} \mathrm{O}_{2}$ production during photosynthesis. $\mathrm{H}_{2} \mathrm{O}_{2}$ generation is associated with oxygen reduction in chloroplast (Figure 1). Mehler (1951) discovered that reduction of $\mathrm{O}_{2}$ lead to the formation of $\mathrm{H}_{2} \mathrm{O}_{2}$ in the presence of light in chloroplast. Moreover, $\mathrm{H}_{2} \mathrm{O}_{2}$ production can also be produced by the reduction of $\mathrm{O}_{2}^{-}$by photosynthetic electron transport (PET) chain components such as $\mathrm{Fe}-\mathrm{S}$ centers, reduced thioredoxin (TRX), ferredoxin and reduced plastoquinone in the chloroplast (Dat et al., 2000). In addition, non-enzymatic production of $\mathrm{H}_{2} \mathrm{O}_{2}$ in chloroplast may be detected at the manganese-containing, oxygen evolving complex which is the donor site of photosystem II (Figure 1). But this process, in most cases, may probably be ignored under physiological conditions.

\section{Mitochondria}

One important source of endogenously produced $\mathrm{H}_{2} \mathrm{O}_{2}$ in plant cell is mitochondria (Dickinson and Chang, 2011). $\mathrm{H}_{2} \mathrm{O}_{2}$ is generated in mitochondria during aerobic respiration when $\mathrm{O}_{2}^{-}$ is produced from complexes I and III in the electron transport chain, which is then rapidly converted to $\mathrm{H}_{2} \mathrm{O}_{2}$ by the enzyme superoxide dismutase (Figure 1).

\section{$\mathrm{H}_{2} \mathrm{O}_{2}$ Removal}

The antioxidant systems that regulate $\mathrm{H}_{2} \mathrm{O}_{2}$ levels consist of both non-enzymatic and enzymatic $\mathrm{H}_{2} \mathrm{O}_{2}$ scavengers (Figure 1). $\mathrm{H}_{2} \mathrm{O}_{2}$-scavenging enzymes include catalase (CAT; Willekens et al., 1997), peroxidase (POX; Fan and Huang, 2012), ascorbate peroxidase (APX) and glutathione reductase (GR; Jahan and Anis, 2014). Some studies revealed that APX was found in the cytosol (Begara-Morales et al., 2013), chloroplasts (Asada, 2006), and mitochondria (Navrot et al., 2007). Meanwhile, CAT can decompose $\mathrm{H}_{2} \mathrm{O}_{2}$ in peroxisome (Nyathi and Baker, 2006). It is quite clear that these enzymes exist in different organelles and they might decrease $\mathrm{H}_{2} \mathrm{O}_{2}$ content efficiently and maintain the stability of membranes.

Ascorbate (AsA) and glutathione (GSH), as non-enzymatic compounds, are constantly participated in regulating ROS level (Kapoor et al., 2015). AsA, a key antioxidant for elimination of $\mathrm{H}_{2} \mathrm{O}_{2}$, can react with $\mathrm{H}_{2} \mathrm{O}_{2}$ directly. $\mathrm{GSH}$ is a crucial antioxidant which may be associated with regenerating AsA, and rapidly oxidizes excess $\mathrm{H}_{2} \mathrm{O}_{2}$. Therefore, $\mathrm{GSH}$ is also involved in regulating $\mathrm{H}_{2} \mathrm{O}_{2}$ level and redox balance in plant cells (Krifka et al., 2012). In fact, $\mathrm{H}_{2} \mathrm{O}_{2}$ homeostasis seems to result in some biological effects on plant cells which may be as a signaling sign in signaling transduction pathway.

\section{Responses to $\mathrm{H}_{2} \mathrm{O}_{2}$ \\ Growth and Development}

Table 1 shows that $\mathrm{H}_{2} \mathrm{O}_{2}$ mediates various developmental and physiological processes in plants. These findings indicate that $\mathrm{H}_{2} \mathrm{O}_{2}$ may affect different parts of plants by increasing endogenous $\mathrm{H}_{2} \mathrm{O}_{2}$ level or by regulating relative gene expression. Also, the change of $\mathrm{H}_{2} \mathrm{O}_{2}$ level may impact metabolic and antioxidant enzyme activity in favor of plant growth and development (Barba-Espín et al., 2011; Liu et al., 2013). However, the mechanisms that allow different $\mathrm{H}_{2} \mathrm{O}_{2}$ function in plants still require examination.

\section{Stress Condition}

Recent studies have demonstrated that $\mathrm{H}_{2} \mathrm{O}_{2}$ is a key signaling molecule in the signaling pathway, which associated with abiotic stress response. A number of discussions showed that $\mathrm{H}_{2} \mathrm{O}_{2}$ could respond to abiotic stresses such as drought (Hameed and Iqbal, 2014; Ashraf et al., 2015), salinity (Sathiyaraj et al., 2014; Mohamed et al., 2015), cold (Orabi et al., 2015), high temperatures (Wang Y. et al., 2014; Wu et al., 2015), UV radiation ( $\mathrm{He}$ et al., 2005), ozone (Oksanen et al., 2004), and heavy metal (Wen et al., 2013; Table 2). It is clear from these studies that $\mathrm{H}_{2} \mathrm{O}_{2}$ could enhance abiotic stress resistance through protecting organelle structure under abiotic stress conditions. For instance, $\mathrm{H}_{2} \mathrm{O}_{2}$ may protect chloroplast ultrastructure to preserve photosynthesis under abiotic stress. Similarly, to improve plant abiotic stress tolerance, $\mathrm{H}_{2} \mathrm{O}_{2}$ may modulate the expression of resistance genes and antioxidant enzyme activities during abiotic stress response.

\section{$\mathrm{H}_{2} \mathrm{O}_{2}$ as a Signaling Molecule in Plant}

Among ROS, $\mathrm{H}_{2} \mathrm{O}_{2}$ has comparatively long life span and small size, which permit it to traverse through cellular membranes to different cellular compartments. García-Mata and Lamattina (2013) found that $\mathrm{H}_{2} \mathrm{O}_{2}$ may move between cells through aquaporin channels for signaling transduction. Increasing evidences point out that $\mathrm{H}_{2} \mathrm{O}_{2}$ signaling may regulate various plant physiological processes. For example, $\mathrm{H}_{2} \mathrm{O}_{2}$ as signaling molecule may participate in nitrosative stress-triggered cell death in kimchi cabbage (Brassica rapa var. glabra Regel) seedlings (Kim et al., 2015). Also, Li et al. (2015) suggested that $\mathrm{H}_{2} \mathrm{O}_{2}$ is involved in signaling crosstalk between $\mathrm{NO}$ and hydrogen sulfide $\left(\mathrm{H}_{2} \mathrm{~S}\right)$ to induce thermotolerance in maize seedlings. Moreover, the interaction among $\mathrm{H}_{2} \mathrm{O}_{2}$, NO and $\mathrm{Ca}^{2+}$ could relieve copper stress in Ulva compressa (González et al., 2012). $\mathrm{H}_{2} \mathrm{O}_{2}$ signaling was also demonstrated to play a salient role in brassinosteroid-regulated stomatal movement (Shi C. et al., 2015). As stated above, $\mathrm{H}_{2} \mathrm{O}_{2}$ as an important signaling molecule may play a significant role at every stage of plant life and under various abiotic stress conditions. $\mathrm{H}_{2} \mathrm{O}_{2}$ signaling appears to crosstalk with many different signaling molecules such as 
TABLE 1 | The developmental and physiological effects of $\mathrm{H}_{2} \mathrm{O}_{2}$ in plants.

\begin{tabular}{|c|c|c|c|c|c|}
\hline $\begin{array}{l}\text { Developmental and } \\
\text { physiological effect }\end{array}$ & Species & Tissue & $\begin{array}{c}\mathrm{H}_{2} \mathrm{O}_{2} \\
\text { production }\end{array}$ & $\mathrm{H}_{2} \mathrm{O}_{2}$-mediated effect & References \\
\hline Seed germination & $\begin{array}{l}\text { Pisum sativum L. } \\
\text { cv. Alaska }\end{array}$ & Seed & + & $\begin{array}{l}\text { Caused carbonylation of proteins and metabolic } \\
\text { enzyme } \\
\text { Up-regulated PSMAPK2 } \\
\text { PSMAPK3 expression }\end{array}$ & Barba-Espín et al., 2011 \\
\hline PCD & $\begin{array}{l}\text { Chlamydomo-nas } \\
\text { reinhardtii }\end{array}$ & & + & $\begin{array}{l}\text { Induced cell death } \\
\text { Increased intracellular } \mathrm{H}_{2} \mathrm{O}_{2} \text { content } \\
\text { Increased antioxidant enzyme activities and analyses } \\
\text { of transcripts }\end{array}$ & \\
\hline Senescence & Lilium & Leaf & + & $\begin{array}{l}\text { Increased vase life and flower diameter } \\
\text { Reduced the degradation of RWC, total chlorophyll } \\
\text { content and water-soluble carbohydrate }\end{array}$ & Liao et al., 2012b \\
\hline \multirow[t]{3}{*}{ Root system development } & Tagetes erecta L. & Root & + & $\begin{array}{l}\text { Increased root length } \\
\text { Increased root number explant }{ }^{-1}\end{array}$ & Liao et al., 2009 \\
\hline & $\begin{array}{l}\text { Arabidopsis } \\
\text { thaliana }\end{array}$ & & & $\begin{array}{l}\text { Accelerated lateral root formation } \\
\text { Increased endogenous } \mathrm{H}_{2} \mathrm{O}_{2} \text { production } \\
\text { Up-regulated relative expression levels of } \mathrm{HY}_{1}\end{array}$ & Ma et al., 2014 \\
\hline & & & & Increased sensitivity of the root elongation zone & $\begin{array}{l}\text { Hernández-Barrera et al., } \\
2015\end{array}$ \\
\hline Stomatal closure & $\begin{array}{l}\text { Arabidopsis } \\
\text { thaliana }\end{array}$ & Leaf & + & Induced stomatal closure & Ge et al., 2015 \\
\hline
\end{tabular}

hormones (Shi C. et al., 2015), protein kinase (González et al., 2012) and many other small signaling molecules (Li et al., 2015). $\mathrm{H}_{2} \mathrm{O}_{2}$ and these signaling molecules may influence each other through various positive and negative feedback loops. Thus, they co-regulate cell division and differentiation, antioxidant system as well as gene expression involved in plant development and defense.

\section{CROSSTALK BETWEEN $\mathrm{H}_{2} \mathrm{O}_{2}$ AND NO}

NO is a diatomic free radical gas. Previous studies suggested that NO could take part in a wide range of physiological processes such as vasorelaxation, nervous system, defense against pathogens in animals (Mayer and Hemmens, 1998). In mammals, NO is synthesized via three different isoforms of NO synthase (NOS) including inducible NOS (iNOS; Nathan and Hibbs, 1991), endothelial NOS (eNOS) and neuronal NOS (nNOS; Förstermann et al., 1994). In plants, NO could be synthesized through enzymatic and non-enzymatic pathways (Figure 2). The enzymatic pathway includes nitrate reductase (NR; Rockel et al., 2002), nitric oxide-like (NOS-like) synthase (Guo et al., 2003), Nitrite-NO reductase (Ni-NOR; Stöhr et al., 2001) and xanthine oxidase (XOR; Corpas et al., 2004) pathways.
The non-enzymatic generation of NO includes nitrification or de-nitrification processes (Skiba et al., 1993, Figure 2).

A plethora of evidences suggest that NO, as a versatile signaling molecule, is involved in regulating every aspect of plant growth and developmental processes such as seed germination (Fan et al., 2013; Wang et al., 2015), flowering (Liu W. W. et al., 2015), root growth and development (Liao et al., 2011; Wu et al., 2014; Xiang et al., 2015), ripening and senescence (Liao et al., 2013; Shi Y. et al., 2015). Meanwhile, as a physiological regulator, NO signaling is involved in mediating stomatal closure (Noelia et al., 2015; Shi K. et al., 2015; Chen et al., 2016), pollen tube growth (Wang et al., 2009). Also, NO plays an essential role in plant disease resistance (Rasul et al., 2012; Kovacs et al., 2015) and responses to various abiotic stresses such as cold (Fan et al., 2015), heat (Yu et al., 2015), salt (Liu W. et al., 2015), drought (Shan et al., 2015), UV-B (Esringu et al., 2015) and heavy metal (Alemayehu et al., 2015; Chen et al., 2015; Kaur et al., 2015).These studies have paved the way to understand the signaling roles of NO which may affect cell metabolism, cellular redox balance and gene expression in plants. The relative target receptor may receive signaling activated by various stimuli. As a result, NO may activate regulatory mechanism to promote developmental and physiological processes and regulate abiotic stress response in plants. 
TABLE 2 | Report on $\mathrm{H}_{2} \mathrm{O}_{2}$-mediated effect during stresses in plants.

\begin{tabular}{|c|c|c|c|c|}
\hline Stress & Plant species & Tissue & $\mathrm{H}_{2} \mathrm{O}_{2}$-mediated effect & References \\
\hline \multirow[t]{2}{*}{ Drought } & Triticum aestivum L. & Leaf & $\begin{array}{l}\text { Increased SOD, POD, CAT activities } \\
\text { Raised total phenolic and reducing sugars content }\end{array}$ & $\begin{array}{l}\text { Hameed and lqbal, } \\
2014\end{array}$ \\
\hline & Zea mays L. & Leaf & $\begin{array}{l}\text { Reduced degradation of chlorophyll increased endogenous } \mathrm{H}_{2} \mathrm{O}_{2}, \mathrm{MDA} \\
\text { contents } \\
\text { Increased antioxidant enzymes activities } \\
\text { Increased ascorbic acid content and ion contents }\end{array}$ & Ashraf et al., 2015 \\
\hline
\end{tabular}

\begin{tabular}{|c|c|c|c|c|}
\hline \multirow[t]{2}{*}{ Salt } & Panax ginseng & Leaf & $\begin{array}{l}\text { Increased chlorophyll and carotenoid content } \\
\text { Increased Relative water content } \\
\text { Increased growth height and dry-weight } \\
\text { Increased antioxidant activity } \\
\text { Up-regulated relative gene expression of defense related genes }\end{array}$ & Sathiyaraj et al., 2014 \\
\hline & Lycopersicon esculentum L. & & $\begin{array}{l}\text { Decreased electrolyte leakage } \\
\text { Increased endogenous } \mathrm{H}_{2} \mathrm{O}_{2} \text { and MDA content } \\
\text { Increased antioxidant enzymes activities } \\
\text { Affect protein pattern and peroxidase enzymes }\end{array}$ & Mohamed et al., 2015 \\
\hline Cold & Lycopersicon esculentum L. & Seedling & $\begin{array}{l}\text { Increased antioxidant enzymes activities } \\
\text { Increased MDA content Decreased electrolyte leakage } \\
\text { Increased total soluble solids }\end{array}$ & Orabi et al., 2015 \\
\hline \multirow[t]{2}{*}{ Heat } & Festuca arundinaceaLolium perenne & Leaf & $\begin{array}{l}\text { Decreased the GSH/GSSG ratio } \\
\text { Increased POD, CAT, APC, GR, and GPX activities }\end{array}$ & Wang Y. et al., 2014 \\
\hline & Arabidopsis thaliana & Seedling & $\begin{array}{l}\text { Increased thermotolerance } \\
\text { Enhanced antioxidant enzyme activities } \\
\text { Increased endogenous NO content } \\
\text { Increased HSFs activity and HSP21 } \\
\text { accumulation }\end{array}$ & Wu et al., 2015 \\
\hline UV-B & Vicia faba L. & Leaf & $\begin{array}{l}\text { Increased endogenous } \mathrm{H}_{2} \mathrm{O}_{2} \text { production } \\
\text { Induced Stomatal closure }\end{array}$ & He et al., 2005 \\
\hline Ozone & Betula papyrifera & Leaf & $\begin{array}{l}\text { Induced proliferation of peroxisomes } \\
\text { Increased Level of gene expression for catalase (Cat) }\end{array}$ & Oksanen et al., 2004 \\
\hline Heavy metal & Zea mays var. rugosa Bonaf & Seedling & $\begin{array}{l}\text { Decreased the activities of proline dehydrogenase } \\
\text { Increased the activities of Arginase and OAT, P5CS and GDH } \\
\text { Up-regulated the expression levels of P5CS, GDH, Arginase, OAT and } \\
\text { ProDH genes }\end{array}$ & Wen et al., 2013 \\
\hline
\end{tabular}

\section{Interaction in Growth and Development}

To date, the interaction between $\mathrm{H}_{2} \mathrm{O}_{2}$ and $\mathrm{NO}$ has been demonstrated clearly in plants. The signaling crosstalk between $\mathrm{H}_{2} \mathrm{O}_{2}$ and $\mathrm{NO}$ has been considered to be an essential factor to influence plant developmental and physiological processes such as leaf cell death (Lin et al., 2012), delay senescence (Iakimova and Woltering, 2015), root growth and development (Liao et al., 2010, 2011), stomatal closure (Huang et al., 2015; Shi K. et al., 2015), and pollen tube growth (Serrano et al., 2012). Table 3 shows the interaction of $\mathrm{H}_{2} \mathrm{O}_{2}$ and $\mathrm{NO}$ at different levels in a great number of developmental and physiological processes in plants. On the one side, $\mathrm{H}_{2} \mathrm{O}_{2}$ may act as a cofactor to promote endogenous NO synthesis. For example, Lin et al. (2012) implied that $\mathrm{H}_{2} \mathrm{O}_{2}$ may stimulate NO production through increasing NR activity in leaves of noe1 plants under high light. Shi C. et al. (2015) reported that $\mathrm{G} \alpha$-activated $\mathrm{H}_{2} \mathrm{O}_{2}$ production may induce $\mathrm{NO}$ synthesis. The research found that NO could modulate stomatal closure in $\mathrm{H}_{2} \mathrm{O}_{2}$ mutants AtrbohF and AtrbohD AtrbohF and in the wild type treated with $\mathrm{H}_{2} \mathrm{O}_{2}$ scavenger and inhibitor. However, $\mathrm{H}_{2} \mathrm{O}_{2}$ did not close or reduce the stomatal closure in mutants Nia1-2 and Nia2-5 Nia1-2, and in the wild type treated c-PTIO or tungstate (Shi C. et al., 2015). These results clearly show that $\mathrm{H}_{2} \mathrm{O}_{2}$ might induce $\mathrm{NO}$ synthesis in stomatal closure. On the other side, $\mathrm{NO}$ may induce $\mathrm{H}_{2} \mathrm{O}_{2}$ generation in plants. Liao et al. (2011) reported cPTIO or L-NAME could inhibit the endogenous $\mathrm{H}_{2} \mathrm{O}_{2}$ generation implying that $\mathrm{NO}$ was required for the production of $\mathrm{H}_{2} \mathrm{O}_{2}$ during adventitious rooting. Meanwhile, NO could mediate antioxidant enzyme activities to influence the $\mathrm{H}_{2} \mathrm{O}_{2}$ level (Zhang et al., 2007). Thus, the interaction of $\mathrm{H}_{2} \mathrm{O}_{2}$ and $\mathrm{NO}$ may trigger a serious of physiological and biological response in plant cells.

\section{Interaction during Abiotic Stress}

Recently, the roles of $\mathrm{H}_{2} \mathrm{O}_{2}$ and $\mathrm{NO}$ signaling and their crosstalk in mediating plant response to abiotic stresses have been largely established (Table 4). 


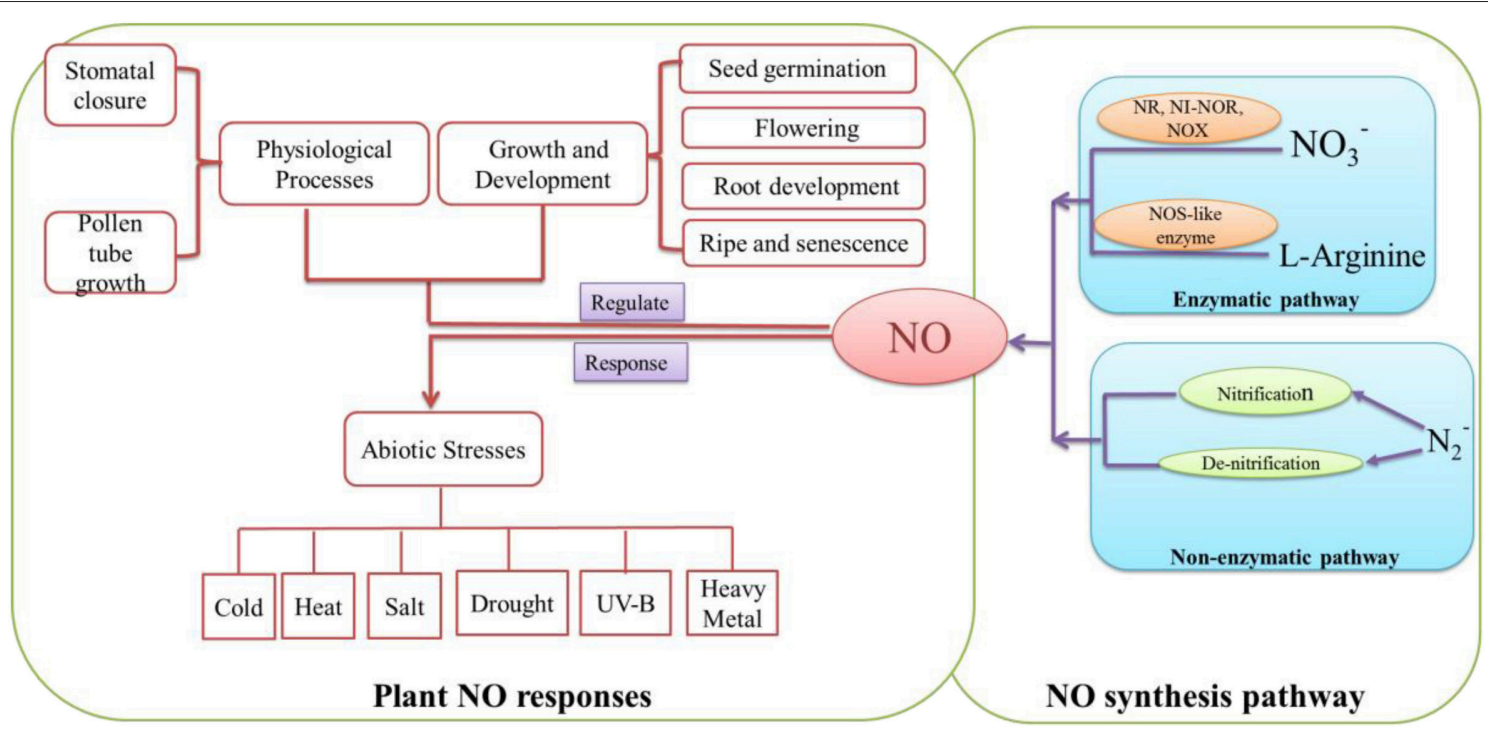

FIGURE 2 | Summary of the main NO systhetic pathways and NO functions in plant growth, development and defense processes. NO may be synthesized by enzymatically and non-enzymatically pathways. In enzymatic pathway, nitrate reductase (NR; Rockel et al., 2002), Nitrite-NO reductase (Ni-NOR; Stöhr et al., 2001) and xanthine oxidase (XOR; Corpas et al., 2004) could convert $\mathrm{NO}_{3}^{-}$and $\mathrm{NO}_{2}^{-}$to NO. Meanwhile, because of NOS-like enzyme (Guo et al., 2003), L-Arginine may be catalyzed to NO. In non-enzymatic pathway, $\mathrm{N}_{2}^{-}$could be transformed to NO through nitrification and denitrification (Skiba et al., 1993). NO plays an important signaling molecule in plant. It could regulate developmental and physiological processes such as seed germination (Wang et al., 2015), root development (Liao et al., 2011) and stomatal closure (Shi C. et al., 2015). Also, it may be involved in response to abiotic stresses such as cold (Fan et al., 2015), salt (Liu W. et al., 2015) and drought (Shan et al., 2015).

TABLE 3 | The developmental and physiological effects of crosstalk between $\mathrm{H}_{2} \mathrm{O}_{2}$ and $\mathrm{NO}$ in plants.

\begin{tabular}{|c|c|c|c|c|}
\hline $\begin{array}{l}\text { Developmental and } \\
\text { physiological effect }\end{array}$ & Species & Tissue & Crosstalk between $\mathrm{H}_{2} \mathrm{O}_{2}$ and $\mathrm{NO}$ mediated effects & References \\
\hline Cell death & Oryza sativa & Leaf & $\begin{array}{l}\mathrm{H}_{2} \mathrm{O}_{2} \text { induced } \mathrm{NR} \text {-dependent } \mathrm{NO} \text { generation } \\
\mathrm{NO} \text { Is required for } \mathrm{H}_{2} \mathrm{O}_{2} \text {-induced leaf cell death increased NR enzyme }\end{array}$ & Lin et al., 2012 \\
\hline Senescence & Lactuca sativa L. & Leaf & $\begin{array}{l}\mathrm{NO} \text { decreased endogenous } \mathrm{H}_{2} \mathrm{O}_{2} \text { content } \\
\text { Delay senescence }\end{array}$ & $\begin{array}{l}\text { lakimova and } \\
\text { Woltering, } 2015\end{array}$ \\
\hline Root growth & $\begin{array}{l}\text { Dendranthema } \\
\text { morifolium } \\
\text { Tagetes erecta L. }\end{array}$ & Root & $\begin{array}{l}\text { Increase the activities of PPO, IAAO and the content of WSC and total nitrogen } \\
\text { Decrease the total polyphenol content } \\
\mathrm{NO} \text { and } \mathrm{H}_{2} \mathrm{O}_{2} \text { may act synergistically to mediate adventitious } \\
\text { root generation and development } \\
\mathrm{NO} \text { may be involved as an upstream signaling molecule for } \mathrm{H}_{2} \mathrm{O}_{2} \text { production }\end{array}$ & $\begin{array}{l}\text { Liao et al., } 2010 \\
\text { Liao et al., } 2011\end{array}$ \\
\hline Pollen tube growth & Olea europaea L. & Flower & $\begin{array}{l}\text { Decreased cell death } \\
\text { Increased nitrated proteins }\end{array}$ & Serrano et al., 2012 \\
\hline Stomatal movement & $\begin{array}{l}\text { Arabidopsis } \\
\text { Vicia faba }\end{array}$ & Leaf & $\begin{array}{l}\mathrm{H}_{2} \mathrm{O}_{2} \text { production was required for } \mathrm{NO} \text { synthesis } \\
\text { Regulated stomatal closure } \\
\text { Regulated stomatal closure } \\
\mathrm{H}_{2} \mathrm{O}_{2} \text { induced NO production }\end{array}$ & $\begin{array}{l}\text { Shi C. et al., } 2015 \\
\text { Huang et al., } 2015\end{array}$ \\
\hline
\end{tabular}

\section{Drought}

Drought stress is a major environmental factor that affects plant growth and development. As reported by Liao et al. (2012a), both $\mathrm{H}_{2} \mathrm{O}_{2}$ and $\mathrm{NO}$ could protect mesophyll cells ultrastructure and improve the photosynthetic level of leaves under drought stress during adventitious rooting in marigold explants. Similarly, the interplay between $\mathrm{H}_{2} \mathrm{O}_{2}$ and $\mathrm{NO}$ signaling may increase the activity of myo-inositol phosphate synthase to alleviate drought stress (Tan et al., 2013). Additionally, Lu et al. (2009) suggested that endogenous $\mathrm{NO}$ and $\mathrm{H}_{2} \mathrm{O}_{2}$ may be involved in $\mathrm{ABA}$-induced drought tolerance of bermudagrass by increasing antioxidant enzyme activities. NO may be considered to be upstream or downstream signaling molecule of $\mathrm{H}_{2} \mathrm{O}_{2}$ (Lu et al., 2009; Liao et al., 2012a). Thus, the interaction between $\mathrm{H}_{2} \mathrm{O}_{2}$ and $\mathrm{NO}$ 
TABLE 4 | Reports on interaction between $\mathrm{H}_{2} \mathrm{O}_{2}$ and $\mathrm{NO}$ involved in abiotic stresses in plants.

\begin{tabular}{|c|c|c|c|c|}
\hline Stress & Plant species & Tissue & Crosstalk between $\mathrm{H}_{2} \mathrm{O}_{2}$ and $\mathrm{NO}$ mediated effects & Reference \\
\hline \multirow[t]{2}{*}{ Salt } & Citrus aurantium L. & Leaf & $\begin{array}{l}\text { Alleviated salinity-induced protein carbonylation } \\
\text { Shifted the accumulation levels of leaf S-nitrosylated proteins } \\
\text { acclimation to salinity } \\
\text { Identified a number of proteins which were modulated by both } \mathrm{H}_{2} \mathrm{O}_{2} \text { and } \mathrm{NO} \text { treatments }\end{array}$ & $\begin{array}{l}\text { Tanou et al., } 2009 \\
\text { Tanou et al., } 2010\end{array}$ \\
\hline & $\begin{array}{l}\text { Populus euphratica } \\
\text { Medicago falcata }\end{array}$ & $\begin{array}{l}\text { shoot } \\
\text { Seedling }\end{array}$ & $\begin{array}{l}\text { Increased K/Na ratio } \\
\text { Stimulated expression of PM H }{ }^{+} \text {-ATPase Induced MfMIPSI transcript } \\
\text { Increased the level of myo-inositol }\end{array}$ & $\begin{array}{l}\text { Zhang et al., } 2007 \\
\text { Tan et al., } 2013\end{array}$ \\
\hline \multirow[t]{2}{*}{ Drought } & Tagetes erecta L. & Root & $\begin{array}{l}\text { Alleviated the destruction of mesophyll cell ultrastructure } \\
\text { Increased leaf chlorophyll content } \\
\text { Mediated chlorophyll fluorescence parameters } \\
\text { Enhanced carbohydrate accumulation } \\
\text { Decreased starch content } \\
\mathrm{H}_{2} \mathrm{O}_{2} \text { generation may be affected by NO}\end{array}$ & Liao et al., $2012 a$ \\
\hline & Tagetes erecta L. & Leaf & $\begin{array}{l}\text { Increased RWC } \\
\text { Decrease ion leakage } \\
\text { Increased antioxidant enzyme, PEPCase, HK activities and MDA content } \\
\mathrm{NO} \text { acted downstream of } \mathrm{H}_{2} \mathrm{O}_{2}\end{array}$ & Lu et al., 2009 \\
\hline \multirow[t]{2}{*}{ UV-B } & Arabidopsis & Leaf & $\begin{array}{l}\mathrm{NO} \text { production depends on } \mathrm{H}_{2} \mathrm{O}_{2} \\
\text { Mediated stomatal closure }\end{array}$ & He et al., 2013 \\
\hline & & & The UV-B Photoreceptor UVR8 was mediated by $\mathrm{H}_{2} \mathrm{O}_{2}$ and $\mathrm{NO}$ & Tossi et al., 2014 \\
\hline \multirow[t]{3}{*}{ Heat } & Zea may L. & seedling & $\begin{array}{l}\text { Improved survival percentage of maize seedlings } \\
\mathrm{H}_{2} \mathrm{O}_{2} \text { increased endogenous } \mathrm{NO} \text { content } \\
\mathrm{H}_{2} \mathrm{O}_{2} \text { may be involved in downstream signal of NO}\end{array}$ & Li et al., 2015 \\
\hline & Arabidopsis & & $\begin{array}{l}\mathrm{NO} \text { is involved in } \mathrm{H}_{2} \mathrm{O}_{2} \text { signaling as a downstream factor. } \\
\text { Increased } \mathrm{HS} \text { factor activity and } \mathrm{HS} \text { protein accumulation. }\end{array}$ & Wang L. et al., 2014 \\
\hline & Triticum aestivum L. & & $\begin{array}{l}\text { Increased seedling resistance } \\
\text { Increased } \mathrm{H}_{2} \mathrm{O}_{2} \text { and } \mathrm{NO} \text { content } \\
\text { Increased survival percentage of seedlings }\end{array}$ & Karpets et al., 2015 \\
\hline \multirow[t]{2}{*}{ Cold } & $\begin{array}{l}\text { Medicago sativa } \\
\text { subsp. falcata }\end{array}$ & Leaf & Mediated cold-induced MFSAMS1 expression & Guo et al., 2014 \\
\hline & $\begin{array}{l}\text { Medicago falcate } \\
\text { Medicago sativa }\end{array}$ & Seedling & $\begin{array}{l}\text { Up-regulated MfMIPSI expression } \\
\text { Increased myo-inositol content }\end{array}$ & Tan et al., 2013 \\
\hline \multirow{2}{*}{$\begin{array}{l}\text { Heavy } \\
\text { metal }\end{array}$} & Ulva compressa & Cell & Increased PDH,IDH,OGDH activity and increased relative transcript levels & González et al., 2012 \\
\hline & Triticum aestivum & Root & $\begin{array}{l}\text { Decreased lipid peroxidation } \\
\text { Increased NOS activity } \\
\text { Increased antioxidative enzyme activities }\end{array}$ & Duan et al., 2015 \\
\hline
\end{tabular}

may alleviate drought stress through up-regulating antioxidant defense system to protect cell membrane and maintain ion homeostasis in plants.

\section{Salt}

The interaction between $\mathrm{H}_{2} \mathrm{O}_{2}$ and $\mathrm{NO}$ plays an important role in plant tolerance to salt stress (Zhang et al., 2007; Tan et al., 2013). Tanou et al. (2009) suggested that $\mathrm{H}_{2} \mathrm{O}_{2}$ and $\mathrm{NO}$ pre-treatments could alleviate salinity-induced protein carbonylation in citrus. The authors suggested an interaction between $\mathrm{H}_{2} \mathrm{O}_{2}$ and $\mathrm{NO}$ during salt stress response. Furthermore, $\mathrm{H}_{2} \mathrm{O}_{2}$ - and NO-responsive proteins have been identified which may further reveal a protein interaction network between $\mathrm{H}_{2} \mathrm{O}_{2}$ and $\mathrm{NO}$ signaling under salt stress (Tanou et al., 2010).

\section{UV-B}

UV-B, a key environmental signal, initiates diverse responses in plants (Jansen and Bornman, 2012).UV-B radiation can also influence plant growth, development, and productivity. It has been shown that the crosstalk between $\mathrm{H}_{2} \mathrm{O}_{2}$ and $\mathrm{NO}$ could be involved in the response to UV-B stress. There was an interrelationship among $\mathrm{G} \alpha$ protein, $\mathrm{H}_{2} \mathrm{O}_{2}$, and $\mathrm{NO}$ during UVB-induced stomatal closure in Arabidopsis leaves (He et al., 2013). This study found that there was a significant increase in $\mathrm{H}_{2} \mathrm{O}_{2}$ or NO levels which associated with stomatal closure in the wild type by UV-B stress. However, these effects were abolished by double mutants of AtrbohD and AtrbohF or Nial mutants. These results strongly suggested that the crosstalk between $\mathrm{H}_{2} \mathrm{O}_{2}$ and NO signaling might play an essential role during UV-B-induced stomatal closure in guard cells. Recently, Tossi et al. (2014) also 


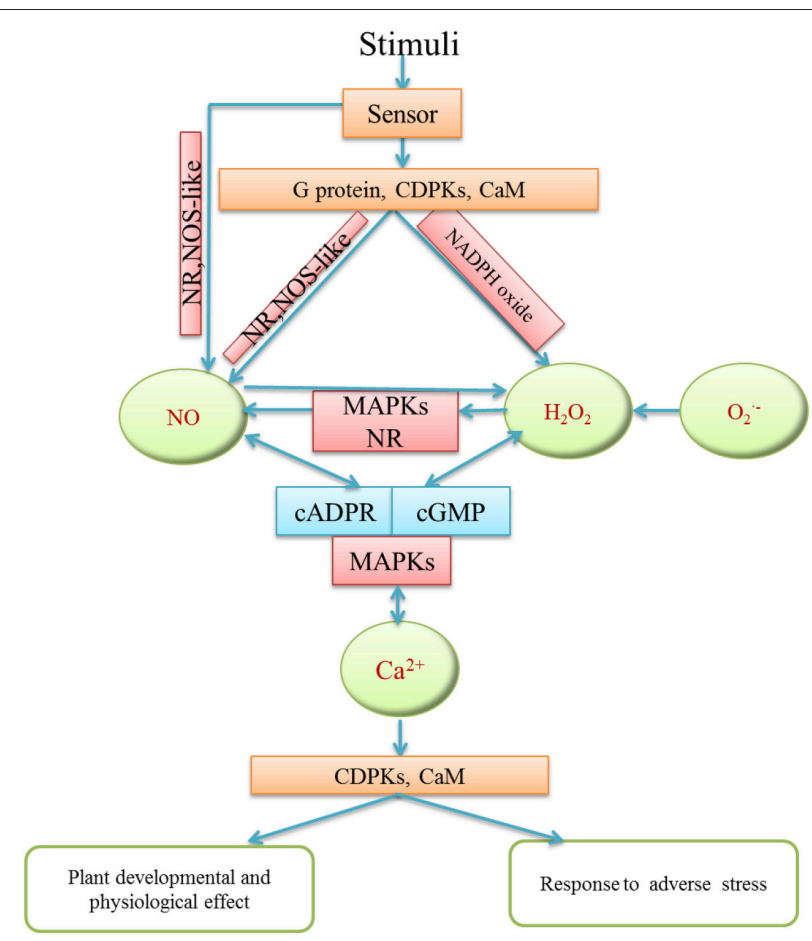

FIGURE 3 | Schematic model of the interaction among $\mathrm{H}_{2} \mathrm{O}_{2}, \mathrm{NO}, \mathrm{Ca}^{2+}$ in different plant physiological and defense processes. $\mathrm{H}_{2} \mathrm{O}_{2}, \mathrm{NO}$ and $\mathrm{Ca}^{2+}$ may receive various stimuli through signaling sensors. They might interact via cross-regulation and transduce signaling to downstream molecules by activating phosphokinase like MAPKs, or relative enzyme activity in order to regulate plant development and growth and abiotic stress responses.

showed a mechanism involving both $\mathrm{H}_{2} \mathrm{O}_{2}$ and $\mathrm{NO}$ generation in response to UV-B exposure. Therefore, the crosstalk between $\mathrm{H}_{2} \mathrm{O}_{2}$ and $\mathrm{NO}$ can regulate stomatal movement to reduce UV-B stress damage to plant cells.

\section{Cold}

Cold stress adversely influences plant growth and development. Guo et al. (2014) reported that the interaction of $\mathrm{H}_{2} \mathrm{O}_{2}$ and NO may affect cold-induced S-adenosylmethionine synthetase and increase cold tolerance through up-regulating polyamine oxidation in Medicago sativa subsp. falcate. Moreover, signaling interplay of $\mathrm{H}_{2} \mathrm{O}_{2}$ and $\mathrm{NO}$ was essential for cold-induced gene expression of falcata myo-inositol phosphate synthase (MfMIPS), which improved tolerance to cold stress (Tan et al., 2013). Thus, the interaction between $\mathrm{H}_{2} \mathrm{O}_{2}$ and $\mathrm{NO}$ may initiate different mechanisms to response to cold stresses.

\section{Heat}

Recently, many studies have been conducted to investigate the relationship between $\mathrm{H}_{2} \mathrm{O}_{2}$ and $\mathrm{NO}$ under heat stress. Li et al. (2015) reported that a signaling crosstalk between $\mathrm{H}_{2} \mathrm{O}_{2}$ and $\mathrm{NO}$ may be involved in inducing thermotolerance in maize seedlings. Moreover, $\mathrm{H}_{2} \mathrm{O}_{2}$ may be upstream signaling of $\mathrm{NO}$ in the heat shock pathway in Arabidopsis seedlings (Wang L. et al., 2014). In addition, treatment with low level of $\mathrm{H}_{2} \mathrm{O}_{2}$ or NO could increase seedling viability under heat resistance (Karpets et al., 2015). These studies support the existence of crosstalk between $\mathrm{H}_{2} \mathrm{O}_{2}$ and $\mathrm{NO}$ in heat responses in plants.

\section{Heavy Metal Stress}

Alberto et al. (2012) suggested that the signaling interaction between $\mathrm{H}_{2} \mathrm{O}_{2}$ and $\mathrm{NO}$ was involved in alleviating copper stress of Ulva compressa through mediating antioxidant enzyme activities and activating relative gene expression. Besides, the interplay of $\mathrm{NO}$ and $\mathrm{H}_{2} \mathrm{O}_{2}$ in wheat seedlings participated in regulating root growth under zinc stress and alleviated zinc stress through increasing antioxidant system, decreasing lipid peroxidation as well as up-regulating resistance gene expression (Duan et al., 2015). Obviously, the crosstalk of $\mathrm{H}_{2} \mathrm{O}_{2}$ and $\mathrm{NO}$ has been found under heavy metal stress condition, which may trigger a variety of antioxidant responses in plants.

As stated above, the physiological effect of $\mathrm{H}_{2} \mathrm{O}_{2}$ and $\mathrm{NO}$ is similar and synergetic. In different cases, these forms of interaction are various. However, the form of $\mathrm{H}_{2} \mathrm{O}_{2}$ and $\mathrm{NO}$ crosstalk depend on plant species and environmental stresses. $\mathrm{H}_{2} \mathrm{O}_{2}$ and $\mathrm{NO}$ could modulate each other through regulating antioxidant enzymes activities and relative gene expression in plants. Meanwhile, $\mathrm{H}_{2} \mathrm{O}_{2}$ and $\mathrm{NO}$ may synergistically regulate many common target genes which were related to signaling transduction, defense reaction, plant hormone interactions, protein transport and metabolism. Therefore, it has a significant meaning to elaborate the mechanism of the interaction between $\mathrm{H}_{2} \mathrm{O}_{2}$ and $\mathrm{NO}$ in plant developmental processes and response to abiotic stresses.

\section{CROSSTALK BETWEEN $\mathrm{H}_{2} \mathrm{O}_{2}$ AND $\mathrm{CA}^{2+}$}

$\mathrm{Ca}^{2+}$ is a widespread signaling molecule in plants. When plants receive stimuli, the change of intracellular $\mathrm{Ca}^{2+}$ concentration may transfer signaling to regulate a series of cellular processes in plants (Kong et al., 2015; Tang et al., 2015). There are various types of $\mathrm{Ca}^{2+}$ receptors and channels in plants such as $\mathrm{Ca}^{2+}$-ATPases (Pászty et al., 2015), $\mathrm{Ca}^{2+}$-binding sensor protein (Wagner et al., 2015), inositol-1,4,5-trisphosphate (IP 3 ; Serrano et al., 2015) and cyclic ADP-ribose (cADPR, Gerasimenko et al., 2015). It is well known that $\mathrm{Ca}^{2+}$ is involved in plant growth and development such as seed germination (Kong et al., 2015), pollen tube growth (Zhou et al., 2014), leaf de-etiolation (Huang et al., 2012), root growth and development (Liao et al., 2012a; Han et al., 2015) and other physiological processes including cell polarity regulation (Zhou et al., 2014; Himschoot et al., 2015), stomatal closure (Zou et al., 2015) and immune response (Seybold et al., 2014). Furthermore, variations in cytosolic free $\mathrm{Ca}^{2+}$ concentration have been demonstrated to response to a wide range of environmental stresses such as heat shock (Urao et al., 1994), drought (Zou et al., 2015), light (Hu et al., 2015), salt (Tepe and Aydemir, 2015), and heavy metal (Li et al., 2016). Because of $\mathrm{Ca}^{2+}$ has various receptors and channels in plants, it may receive different upstream signaling molecules quickly and then respond to abiotic stress. 


\section{Interaction in Growth and Development}

Crosstalk between $\mathrm{H}_{2} \mathrm{O}_{2}$ and $\mathrm{Ca}^{2+}$ occurs in plant cells (Table 5). For example, exogenous $\mathrm{H}_{2} \mathrm{O}_{2}$ caused transiently dose-dependent increase in $\mathrm{Ca}^{2+}$ influx in Arabidopsis thaliana root epidermis (Demidchik et al., 2007). Two $\mathrm{Ca}^{2+}$ channels could be regulated by $\mathrm{H}_{2} \mathrm{O}_{2}$ level in root elongation zone. Han et al. (2015) demonstrated that $\mathrm{H}_{2} \mathrm{O}_{2}$ signaling could induce root elongation by mediating $\mathrm{Ca}^{2+}$ influx in the plasma membrane of root cells in Arabidopsis seedlings. Richards et al. (2014) also suggested that Annexin 1, a Ca ${ }^{2+}$ transport protein, may regulate $\mathrm{H}_{2} \mathrm{O}_{2}$-induced $\mathrm{Ca}^{2+}$ signature in Arabidopsis thaliana roots to promote root growth and development. Additionally, $\mathrm{Ca}^{2+}$ signaling was involved in $\mathrm{H}_{2} \mathrm{O}_{2}$-induced adventitious rooting in marigold because removal of $\mathrm{Ca}^{2+}$ could inhibit $\mathrm{H}_{2} \mathrm{O}_{2}$-induced adventitious root development (Liao et al., 2012a). Interestingly, $\mathrm{Wu}$ et al. (2010)'s findings strongly suggested that spermidine oxidase (Spd)-derived $\mathrm{H}_{2} \mathrm{O}_{2}$ signaling may mediate $\mathrm{Ca}^{2+}$ influx. Spd was probably related to downstream induction of $\mathrm{H}_{2} \mathrm{O}_{2}$ signaling and then $\mathrm{H}_{2} \mathrm{O}_{2}$ activated $\mathrm{Ca}^{2+}$-permeable channels during pollen tube growth (Wu et al., 2010). Cross talk between $\mathrm{Ca}^{2+}{ }_{-}$Calmodulin $(\mathrm{CaM})$ and $\mathrm{H}_{2} \mathrm{O}_{2}$ also played a significant role in antioxidant defense in ABA signaling in maize leaves (Hu et al., 2007; Table 5). Thus, the signaling crosstalk between $\mathrm{H}_{2} \mathrm{O}_{2}$ and $\mathrm{Ca}^{2+}$ may affect every stage of plant development by modulating cell elongation and division, antioxidant enzyme activity and gene expression. $\mathrm{H}_{2} \mathrm{O}_{2}$ may activate $\mathrm{Ca}^{2+}$ receptors and target proteins to increase $\left[\mathrm{Ca}^{2+}\right]_{\text {cyt }}$ level and $\mathrm{Ca}^{2+}$ may induce endogenous $\mathrm{H}_{2} \mathrm{O}_{2}$ generation during plant growth and development.

\section{Interaction in Abiotic Stress}

Clearly, correlations also exist between $\mathrm{H}_{2} \mathrm{O}_{2}$ and $\mathrm{Ca}^{2+}$ in response to abiotic stresses in plants (Table 6). Shoresh et al. (2011) investigated that supplemental $\mathrm{Ca}^{2+}$ had a significant effect on $\mathrm{H}_{2} \mathrm{O}_{2}$ metabolism and regulating leaves and roots growth in maize under salt stress. The authors indicated that extracellular $\mathrm{Ca}^{2+}$ may modulate endogenous $\mathrm{H}_{2} \mathrm{O}_{2}$ levels through activating polyamine oxidase activity. Also, salt stress may induce $\mathrm{H}_{2} \mathrm{O}_{2}$ accumulation in $\mathrm{Ca}^{2+}$-dependent salt resistance pathway in Arabidopsis thaliana roots (Li et al., 2011). Moreover, Lu et al. (2013) suggested that exogenous $\mathrm{H}_{2} \mathrm{O}_{2}$ and $\mathrm{Ca}^{2+}$ may mediate root ion fluxes in mangrove species under $\mathrm{NaCl}$ stress. Obviously, $\mathrm{H}_{2} \mathrm{O}_{2}$ may interact with $\mathrm{Ca}^{2+}$ under salt stress in plants through mediating root ion balance, increasing antioxidant enzymatic activity and upregulating the expression of related genes. Moreover, $\mathrm{H}_{2} \mathrm{O}_{2}$ and $\mathrm{Ca}^{2+}$ signaling were also involved in $\mathrm{ABA}$ responses to drought stress in Arabidopsis thaliana through $\mathrm{Ca}^{2+}$-dependent protein kinase8 (CPK8) which could regulate catalase3 (CAT3) activity mediating stomatal movement (Zou et al., 2015). In addition, Qiao et al. (2015) reported that a $\mathrm{Ca}^{2+}$-binding protein (rice annexin OsANN1) could enhance heat stress tolerance by modulating $\mathrm{H}_{2} \mathrm{O}_{2}$ production. Over production of $\mathrm{H}_{2} \mathrm{O}_{2}$ induced by heat stress increased OsANN1 expression and up-regulated the level of $S O D$ and CAT expression, which constructed a signaling mechanism for stress defense in plants (Qiao et al., 2015). Until now, the signaling crosstalk between
$\mathrm{H}_{2} \mathrm{O}_{2}$ and $\mathrm{Ca}^{2+}$ may regulate various responses to abiotic stresses in plants. It may be connected with the regulation of antioxidant system. Thus, the interaction between $\mathrm{H}_{2} \mathrm{O}_{2}$ and $\mathrm{Ca}^{2+}$ may increase antioxidant enzyme activities such as APX, SOD, and GR. These antioxidant enzymes may alleviate stress damages in plants. In addition, the crosstalk between $\mathrm{H}_{2} \mathrm{O}_{2}$ and $\mathrm{Ca}^{2+}$ could regulate gene expression level and induce protein interactions.

It appears that the interrelationship between $\mathrm{H}_{2} \mathrm{O}_{2}$ and $\mathrm{Ca}^{2+}$ may be involved in various aspects of plant growth and development processes and abiotic stress responses. In fact, the change of $\mathrm{Ca}^{2+}$ concentration is closely related to $\mathrm{H}_{2} \mathrm{O}_{2}$ burst in plant cells. The combination of $\mathrm{H}_{2} \mathrm{O}_{2}$ and $\mathrm{Ca}^{2+}$ may play crucial roles in plants. Different plants even different parts of the same plant may have different modulation mechanisms. Thus, relationship between $\mathrm{H}_{2} \mathrm{O}_{2}$ and $\mathrm{Ca}^{2+}$ signaling in plants is very complex. The interplay of $\mathrm{H}_{2} \mathrm{O}_{2}, \mathrm{Ca}^{2+}$ and its mechanism need to be illustrated clearly in the future.

\section{CROSSTALK AMONG $\mathrm{H}_{2} \mathrm{O}_{2}$, NO AND $\mathrm{CA}^{2+}$}

It has been suggested that there is a connection among $\mathrm{H}_{2} \mathrm{O}_{2}$, $\mathrm{NO}$, and $\mathrm{Ca}^{2+}$ in plants. $\mathrm{H}_{2} \mathrm{O}_{2}, \mathrm{NO}$, and $\mathrm{Ca}^{2+}$ may act as essential signaling molecules which may form a complex signaling network to regulate different developmental and physiological processes in plants (Figure 3). For instance, during adventitious rooting of mung bean, $\mathrm{Ca}^{2+}$ signaling played a pivotal role and functioned as a downstream molecule of $\mathrm{H}_{2} \mathrm{O}_{2}$ and $\mathrm{NO}$ signal pathway (Li and Xue, 2010; Figure 3). Similarly, there is a possible relationship among $\mathrm{H}_{2} \mathrm{O}_{2}$, $\mathrm{NO}$ and $\mathrm{Ca}^{2+} / \mathrm{CaM}$ during adventitious rooting in marigold explants (Liao et al., 2012a). The authors found that exogenous $\mathrm{NO}$ and $\mathrm{H}_{2} \mathrm{O}_{2}$ promoted adventitious root development in marigold explants through increasing endogenous $\mathrm{Ca}^{2+}$ and CaM levels. Moreover, $\mathrm{H}_{2} \mathrm{O}_{2}$, $\mathrm{NO}$ and $\mathrm{Ca}^{2+}$ were also involved in oligochitosan-induced programmed cell death in tobacco suspension cells (Zhang et al., 2012). Pharmacological experiments revealed that $\mathrm{Ca}^{2+}$ signaling induced $\mathrm{NO}$ accumulation through inducing $\mathrm{H}_{2} \mathrm{O}_{2}$ generation during stomatal closure in Arabidopsis guard cells (Li et al., 2009). Furthermore, Wang et al. (2011) suggested a functional correlationship among $\mathrm{H}_{2} \mathrm{O}_{2}$, calcium-sensing receptor (CAS) and $\mathrm{NO}$ in $\mathrm{Ca}^{2+}$-dependent guard cell signaling. It was shown that CAS may transduce $\mathrm{Ca}^{2+}$ signaling through activating its downstream target $\mathrm{NO}$ and $\mathrm{H}_{2} \mathrm{O}_{2}$ signaling pathway (Wang et al., 2011). Therefore, it is thus clear that the interplay of $\mathrm{H}_{2} \mathrm{O}_{2}, \mathrm{NO}$, and $\mathrm{Ca}^{2+}$ may have an significant effect on plant growth and physiological processes through promoting cell proliferation, controlling cell metabolism, meanwhile, regulating modes of cell death. Moreover, Vandelle et al. (2006) has reported that $\mathrm{NO}$ and $\mathrm{H}_{2} \mathrm{O}_{2}$ synthesis could also act upstream to increase cytosolic $\mathrm{Ca}^{2+}$ concentration during hypersensitive response (HR) through activating plasma membrane- and intracellular membrane-associated $\mathrm{Ca}^{2+}$ channels. Besides, the interaction among $\mathrm{H}_{2} \mathrm{O}_{2}, \mathrm{NO}$, and $\mathrm{Ca}^{2+}$ signaling may regulate ABA-induced antioxidant defense in maize (Ma et al., 2012). Obviously, the mutual effect among $\mathrm{H}_{2} \mathrm{O}_{2}$, NO and $\mathrm{Ca}^{2+}$ 
TABLE 5 | The developmental and physiological effects of crosstalk between $\mathrm{H}_{2} \mathrm{O}_{2}$ and $\mathrm{Ca}^{2+}$ in plants.

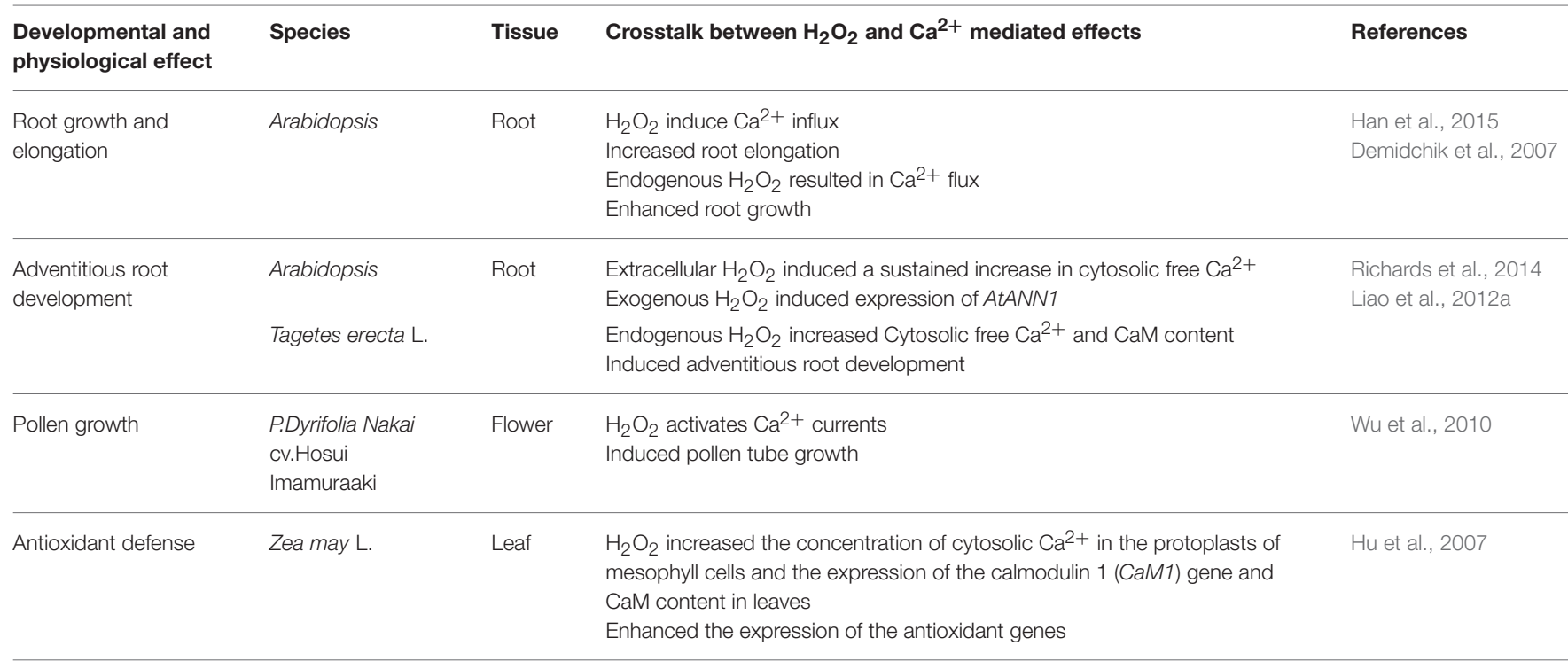

TABLE 6 | Reports on interaction between $\mathrm{H}_{2} \mathrm{O}_{2}$ and $\mathrm{Ca}^{2+}$ involved in abiotic stresses in plants.

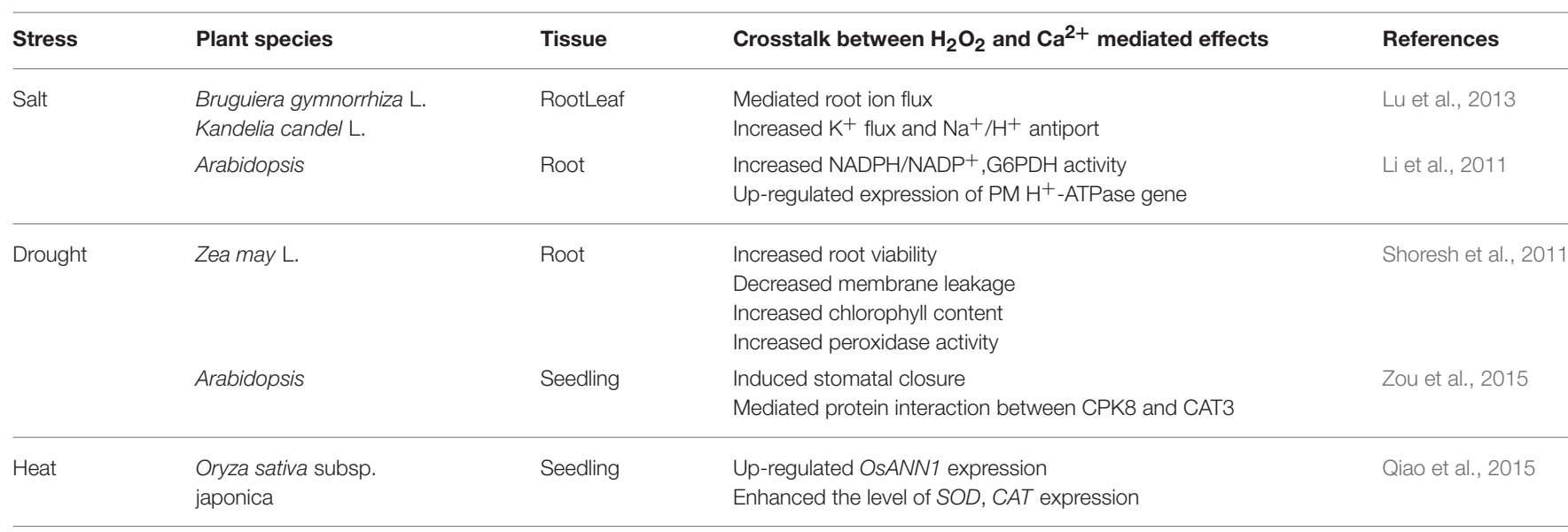

may increase antioxidant system and induce disease defense in plants.

Furthermore, the interplay among $\mathrm{H}_{2} \mathrm{O}_{2}, \mathrm{NO}$, and $\mathrm{Ca}^{2+}$ also have an effect on abiotic stress response in plants. For example, Lang et al. (2014) reported that NO likely interacted with $\mathrm{Ca}^{2+}$ and $\mathrm{H}_{2} \mathrm{O}_{2}$ in Aegiceras corniculatum to up-regulate $\mathrm{Na}^{+} / \mathrm{H}^{+}$antiport system of plasma membrane under salt stress. There were species-specific interactions between $\mathrm{H}_{2} \mathrm{O}_{2}, \mathrm{Ca}^{2+}$, $\mathrm{NO}$, and ATP in salt-induced reduction of $\mathrm{K}^{+}$efflux (Lang et al., 2014). Moreover, there was a crosstalk among $\mathrm{H}_{2} \mathrm{O}_{2}$, $\mathrm{NO}$, and $\mathrm{Ca}^{2+}$ when Ulva compressa exposed to copper excess and the interaction had a significant effect on transcriptional activation of target genes (Alberto et al., 2012). The $\mathrm{H}_{2} \mathrm{O}_{2}$ induced $\mathrm{NO}$ generation could be inhibited by $\mathrm{Ca}^{2+}$ channel blockers, implicating that $\mathrm{Ca}^{2+}$ may mediate the effect of $\mathrm{H}_{2} \mathrm{O}_{2}$ on NO production. Furthermore, $\mathrm{Ca}^{2+}$ release through different type of $\mathrm{Ca}^{2+}$ channels was also shown to be activated by NO and $\mathrm{H}_{2} \mathrm{O}_{2}$ (Alberto et al., 2012; Figure 3). The interrelationship between $\mathrm{H}_{2} \mathrm{O}_{2}$, NO and $\mathrm{Ca}^{2+}$ may provide additional layers of responses to abiotic stresses through controlling ion transport, increasing antioxidant enzyme activities and affecting expression of resistance genes, indicating a feedback mechanism between $\mathrm{H}_{2} \mathrm{O}_{2}$, NO and $\mathrm{Ca}^{2+}$ under abiotic stresses. In a word, the combination of these findings strongly supports the view that there has an interaction among $\mathrm{H}_{2} \mathrm{O}_{2}, \mathrm{NO}$, and $\mathrm{Ca}^{2+}$ signaling pathway in plant growth, development and abiotic stress responses. During signaling transduction, $\mathrm{Ca}^{2+}$ signaling could be activated by $\mathrm{H}_{2} \mathrm{O}_{2}$ and $\mathrm{NO}$; it could also regulate $\mathrm{H}_{2} \mathrm{O}_{2}$ and $\mathrm{NO}$ signaling. $\mathrm{Ca}^{2+}$ may act as a point of signaling convergence between $\mathrm{H}_{2} \mathrm{O}_{2}$ and $\mathrm{NO}$ signaling pathways in plants. However, the network of $\mathrm{H}_{2} \mathrm{O}_{2}, \mathrm{NO}$, and $\mathrm{Ca}^{2+}$ seems to be intricate and multidimensional. Therefore, considerably more work will need to be done to determine the interaction among $\mathrm{H}_{2} \mathrm{O}_{2}$, NO and $\mathrm{Ca}^{2+}$ signaling in plants. 


\section{CONCLUSION}

$\mathrm{H}_{2} \mathrm{O}_{2}$ was once considered as a poisonous molecule in plants. Based on current studies, $\mathrm{H}_{2} \mathrm{O}_{2}$ may be a vital signaling molecule which controls plant growth and development. Interestingly, NO and $\mathrm{Ca}^{2+}$ which also act as the key component of signaling transduction in plants seem to be as upstream or downstream signaling molecules of $\mathrm{H}_{2} \mathrm{O}_{2}$. Meanwhile, $\mathrm{H}_{2} \mathrm{O}_{2}$ modulates $\mathrm{NO}$ and $\mathrm{Ca}^{2+}$ signaling pathways. There is a complex interactive network among $\mathrm{H}_{2} \mathrm{O}_{2}, \mathrm{NO}$, and $\mathrm{Ca}^{2+}$ in plants. Moreover, the interplay among them has functional implications for regulating developmental and physiological processes which may increase the possibility of signal reception and transduction in plants. Future work will need to focus on the molecular mechanism of the interplay among $\mathrm{H}_{2} \mathrm{O}_{2}, \mathrm{NO}$, and $\mathrm{Ca}^{2+}$ during signaling transduction in plants.

\section{REFERENCES}

Alberto, G., Cabrera, M. D., Josefa, H., Contreras, R. A., Bernardo, M., and Alejandra, M. (2012). Cross talk among calcium, hydrogen peroxide, and nitric oxide and activation of gene expression involving calmodulins and calciumdependent protein kinases in ulva compressa exposed to copper excess. Plant Physiol. 158, 1451-1462. doi: 10.1104/pp.111.191759

Alemayehu, A., Zelinová, V., Boèová, B., Huttová, J., Mistrík, I., and Tamás, L. (2015). Enhanced nitric oxide generation in root transition zone during the early stage of cadmium stress is required for maintaining root growth in barley. Plant Soil 390, 213-222. doi: 10.1007/s11104-015-2397-5

Asada, K. (2006). Production and scavenging of reactive oxygen species in chloroplasts and their functions. Plant Physiol. 141, 391-396. doi: 10.1104/pp.106.082040

Ashraf, M. A., Rasheed, R., Hussain, I., Iqbal, M., Haider, M. Z., Parveen, S., et al. (2015). Hydrogen peroxide modulates antioxidant system and nutrient relation in maize (Zea mays L.) under water-deficit conditions. Arch. Agron. Soil Sci. 61, 507-523. doi: 10.1080/03650340.2014.938644

Barba-Espín, G., Diaz-Vivancos, P., Job, D., Belghazi, M., Job, C., and Hernández, J. A. (2011). Understanding the role of $\mathrm{H}_{2} \mathrm{O}_{2}$ during pea seed germination: a combined proteomic and hormone profiling approach. Plant Cell Environ. 34, 1907-1919. doi: 10.1111/j.1365-3040.2011.02386.x

Begara-Morales, J. C., Sánchez-Calvo, B., Chaki, M., Valderrama, R., Mata-Pérez, C., López-Jaramillo, J., et al. (2013). Dual regulation of cytosolic ascorbate peroxidase (APX) by tyrosine nitration and S-nitrosylation. J. Exp. Bot. 65, 527-538. doi: 10.1093/jxb/ert396

Ben Rejeb, K., Vos, L. D., Le Disquet, I., Leprince, A. S., Bordenave, M., Maldiney, R., et al. (2015). Hydrogen peroxide produced by NADPH oxidases increases proline accumulation during salt or mannitol stress in Arabidopsis thaliana. New Phytol. 208, 1138-1148. doi: 10.1111/nph.13550

Brewer, T. F., Garcia, F. J., Onak, C. S., Carroll, K. S., and Chang, C. J. (2015). Chemical approaches to discovery and study of sources and targets of hydrogen peroxide redox signaling through NAPDH oxidase proteins. Annu. Rev. Biochem. 84, 765-790. doi: 10.1146/annurev-biochem-060614-034018

Brychkova, G., Yarmolinsky, D., Fluhr, R., and Sagi, M. (2012). The determination of sulfite levels and its oxidation in plant leaves. Plant Sci. 190, 123-130. doi: 10.1016/j.plantsci.2012.04.004

Chang, Q., and Tang, H. (2014). Optical determination of glucose and hydrogen peroxide using a nanocomposite prepared from glucose oxidase and magnetite nanoparticles immobilized on graphene oxide.Microchim. Acta 181, 527-534. doi: 10.1007/s00604-013-1145-x

Chen, J., Xiang, L., Chao, W., Yin, S. S., Li, X. L., Hu, W. J., et al. (2015). Nitric oxide ameliorates zinc oxide nanoparticles-induced phytotoxicity in rice seedlings. J. Hazard. Mater. 297, 173-182. doi: 10.1016/j.jhazmat.2015. 04.077

\section{AUTHOR CONTRIBUTIONS}

$\mathrm{LN}$ wrote the paper. WL provided the idea and revised the paper.

\section{ACKNOWLEDGMENTS}

This research was supported by the National Natural Science Foundation of China (Nos. 31160398 and 31560563), the Post Doctoral Foundation of China (Nos. 20100470887 and 2012T50828), the Key Project of Chinese Ministry of Education (No. 211182), the Research Fund for the Doctoral Program of Higher Education (No. 20116202120005), the Natural Science Foundation of Gansu References Province, China (Nos. 1308RJZA179 and 1308RJZA262), and the Fundamental Research Funds for Universities in Gansu, P. R. China.

Chen, Z. H., Wang, Y. Z., Wang, J. W., Babla, M., Zhao, C., García-Mata, C., et al. (2016). Nitrate reductase mutation alters potassium nutrition as well as nitric oxide-mediated control of guard cell ion channels in Arabidopsis. New Phytol. 209, 1456-1469. doi: 10.1111/nph.13714

Cheng, X. X., Yu, M., Zhang, N., Zhou, Z. Q., Xu, Q. T., Mei, F. Z., et al. (2015) Reactive oxygen species regulate programmed cell death progress of endosperm in winter wheat (Triticum aestivum L.) under waterlogging. Protoplasma. doi: 10.1007/s00709-015-0811-8. [Epub ahead of print].

Cona, A., Rea, G., Botta, M., Corelli, F., Federico, R., and Angelini, R. (2006). Flavin-containing polyamine oxidase is a hydrogen peroxide source in the oxidative response to the protein phosphatase inhibitor cantharidin in Zea mays L. J. Exp. Bot. 57, 2277-2289. doi: 10.1093/jxb/erj195

Corpas, F. J., Barroso, J. B., and Del Río, L. A. (2004). Enzymatic sources of nitric oxide in plant cells-beyond one protein-one function. New Phytol. 162, 246-248. doi: 10.1111/j.1469-8137.2004.01058.x

Dat, J., Vandenabeele, S., Vranová, E., Van Montagu, M., Inzé, D., and Van Breusegem, F. (2000). Dual action of the active oxygen species during plant stress responses. Cell Mol. Life Sci.57, 779-795. doi: 10.1007/s000180050041

Demidchik, V., Shabala, S. N., and Davies, J. M. (2007). Spatial variation in $\mathrm{H}_{2} \mathrm{O}_{2}$ response of Arabidopsis thaliana root epidermal $\mathrm{Ca}^{2+}$ flux and plasma membrane $\mathrm{Ca}^{2+}$ channels. Plant J. 49, 377-386. doi: 10.1111/j.1365313X.2006.02971.x

Dickinson, B. C., and Chang, C. J. (2011). Chemistry and biology of reactive oxygen species in signaling or stress responses. Nat. Chem. Biol. 7, 504-511. doi: $10.1038 /$ nchembio. 607

Duan, X., Li, X., Ding, F., Zhao, J., Guo, A., Zhang, L., et al. (2015). Interaction of nitric oxide and reactive oxygen species and associated regulation of root growth in wheat seedlings under zinc stress. Ecotox. Environ. Safe 113, 95-102. doi: 10.1016/j.ecoenv.2014.11.030

Esringu, A., Aksakal, O., Tabay, D., and Kara, A. A. (2015). Effects of sodium nitroprusside (SNP) pretreatment on UV-B stress tolerance in lettuce (Lactuca sativa L.) seedlings. Environ. Sci. Pollut. Res. 23, 589-597. doi: 10.1007/s11356015-5301-1

Fan, H. F., Du, C. X., Ding, L., and Xu, Y. L. (2013). Effects of nitric oxide on the germination of cucumber seeds and antioxidant enzymes under salinity stress. Acta Physiol. Plant 35, 2707-2719. doi: 10.1007/s11738-013-1303-0

Fan, J., Chen, K., Amombo, E., Hu, Z., Chen, L., and Fu, J. (2015). Physiological and molecular mechanism of nitric oxide (NO) involved in bermudagrass response to cold stress. PLOS ONE 10:e0132991. doi: 10.1371/journal.pone.0132991

Fan, Y., and Huang, Y. (2012). The effective peroxidase-like activity of chitosan-functionalized $\mathrm{CoFe}_{2} \mathrm{O}_{4}$ nanoparticles for chemiluminescence sensing of hydrogen peroxide and glucose. Analyst 137, 1225-1231. doi: 10.1039/c2an16105b

Förstermann, U., Closs, E. I., Pollock, J. S., Nakane, M., Schwarz, P., Gath, I., et al. (1994). Nitric oxide synthase isozymes. Characterization, 
purification, molecular cloning, and functions. Hypertension 23, 1121-1131. doi: 10.1161/01.HYP.23.6.1121

Foyer, C. H., and Noctor, G. (2003). Redox sensing and signalling associated with reactive oxygen in chloroplasts, peroxisomes and mitochondria. Physiol. Plant 119, 355-364. doi: 10.1034/j.1399-3054.2003.00223.x

Francoz, E., Ranocha, P., Nguyen-Kim, H., Jamet, E., Burlat, V., and Dunand, C. (2015). Roles of cell wall peroxidases in plant development. Phytochemistry 112, 15-21. doi: 10.1016/j.phytochem.2014.07.020

García-Mata, C., and Lamattina, L. (2013). Gasotransmitters are emerging as new guard cell signaling molecules and regulators of leaf gas exchange. Plant Sci. 201, 66-73. doi: 10.1016/j.plantsci.2012.11.007

Ge, X. M., Cai, H. L., Lei, X., Zou, X., Yue, M., and He, J. M. (2015). Heterotrimeric $\mathrm{G}$ protein mediates ethylene-induced stomatal closure via hydrogen peroxide synthesis in Arabidopsis. Plant J. 82, 138-150. doi: 10.1111/tpj.12799

Gerasimenko, J. V., Charlesworth, R. M., Sherwood, M. W., Ferdek, P. E., Mikoshiba, K., Parrington, J., et al. (2015). Both RyRs and TPCs are required for NAADP-induced intracellular $\mathrm{Ca}^{2+}$ release. Cell Calcium 58, 237-245. doi: 10.1016/j.ceca.2015.05.005

González, A., de los Ángeles Cabrera, M., Henríquez, M. J., Contreras, R. A., Morales, B., and Moenne, A. (2012). Cross talk among calcium, hydrogen peroxide, and nitric oxide and activation of gene expression involving calmodulins and calcium-dependent protein kinases in Ulva compressa exposed to copper excess. Plant Physiol. 158, 1451-1462. doi: 10.1104/pp.111.191759

Grivennikova, V. G., and Vinogradov, A. D. (2013). Partitioning of superoxide and hydrogen peroxide production by mitochondrial respiratory complex I. BBA-MOL. Cell. Res. 1827, 446-454. doi: 10.1016/j.bbabio.2013.01.002

Guo, F., Okamoto, M., and Crawford, N. M. (2003). Identification of a plant nitric oxide synthase gene involved in hormonal signaling. Science 302, 100-103. doi: $10.1126 /$ science. 1086770

Guo, Z., Tan, J., Zhuo, C., Wang, C., Xiang, B., and Wang, Z. (2014). Abscisic acid, $\mathrm{H}_{2} \mathrm{O}_{2}$ and nitric oxide interactions mediated cold-induced Sadenosylmethionine synthetase in Medicago sativa subsp. falcata that confers cold tolerance through up-regulating polyamine oxidation. Plant Biotechnol. J. 12, 601-612. doi: 10.1111/pbi.12166

Hameed, A., and Iqbal, N. (2014). Chemo-priming with mannose, mannitol and $\mathrm{H}_{2} \mathrm{O}_{2}$ mitigate drought stress in wheat. Cereal Res. Commun. 42, 450-462. doi: 10.1556/CRC.2013.0066

Han, S., Fang, L., Ren, X., Wang, W., and Jiang, J. (2015). MPK6 controls $\mathrm{H}_{2} \mathrm{O}_{2}$-induced root elongation by mediating $\mathrm{Ca}^{2+}$ influx across the plasma membrane of root cells in Arabidopsis seedlings. New Phytol. 205, 695-706. doi: 10.1111/nph.12990

He, J. M., Ma, X. G., Zhang, Y., Sun, T. F., Xu, F. F., Chen, Y. P., et al. (2013). Role and interrelationship of $\mathrm{G} \alpha$ protein, hydrogen peroxide, and nitric oxide in ultraviolet B-induced stomatal closure in Arabidopsis leaves. Plant Physiol. 161, 1570-1583. doi: 10.1104/pp.112.211623

He, J. M., Xu, H., She, X. P., Song, X. G., and Zhao, W. M. (2005). The role and the interrelationship of hydrogen peroxide and nitric oxide in the UV-Binduced stomatal closure in broad bean. Funct. Plant Biol. 32, 237-247. doi: 10.1071/FP04185

Hernández-Barrera, A., Velarde-Buendía, A., Zepeda, I., Sanchez, F., Quinto, C., Sánchez-Lopez, R., et al. (2015). Hyper, a hydrogen peroxide sensor, indicates the sensitivity of the Arabidopsis root elongation zone to aluminum treatment. Sensors 15, 855-867. doi: 10.3390/s150100855

Himschoot, E., Beeckman, T., Friml, J., and Vanneste, S. (2015). Calcium is an organizer of cell polarity in plants. Biochim. Biophys. Acta 1853, 2168-2172. doi: 10.1016/j.bbamcr.2015.02.017

Hu, X., Bidney, D. L., Yalpani, N., Duvick, J. P., Crasta, O., Folkerts, O., et al. (2003). Overexpression of a gene encoding hydrogen peroxide-generating oxalate oxidase evokes defense responses in sunflower. Plant Physiol. 133, 170-181. doi: 10.1104/pp.103.024026

Hu, X., Jiang, M., Zhang, J., Zhang, A., Lin, F., and Tan, M. (2007). Calciumcalmodulin is required for abscisic acid-induced antioxidant defense and functions both upstream and downstream of $\mathrm{H}_{2} \mathrm{O}_{2}$ production in leaves of maize (Zea mays) plants. New Phytol. 173, 27-38. doi: 10.1111/j.14698137.2006.01888.x

Hu, Z., Li, T., Zheng, J., Yang, K., He, X., and Leng, P. (2015). Ca ${ }^{2+}$ signal contributing to the synthesis and emission of monoterpenes regulated by light intensity in Lilium 'siberia'. Plant Physiol. Biochem. 91, 1-9. doi: 10.1016/j.plaphy.2015.03.005

Huang, A. X., Wang, Y. S., She, X. P., Mu, J., and Zhao, J. L. (2015). Copper amine oxidase-catalysed hydrogen peroxide involves production of nitric oxide in darkness-induced stomatal closure in broad bean. Funct. Plant Biol. 42, 1057-1067. doi: 10.1071/FP15172

Huang, S. S., Chen, J., Dong, X. J., Patton, J., Pei, Z. M., and Zheng, H. L. (2012). Calcium and calcium receptor CAS promote Arabidopsis thaliana de-etiolation. Physiol. Plant. 144, 73-82. doi: 10.1111/j.1399-3054.2011. 01523.x

Iakimova, E. T., and Woltering, E. J. (2015). Nitric oxide prevents wound-induced browning and delays senescence through inhibition of hydrogen peroxide accumulation in fresh-cut lettuce. Innov. Food Sci. Emerg. Technol. 30, 157-169. doi: 10.1016/j.ifset.2015.06.001

Jahan, A. A., and Anis, M. (2014). Changes in antioxidative enzymatic responses during acclimatization of in vitro raised plantlets of Cardiospermum halicacabum L. against oxidative stress. J. Plant Physiol. Pathol. 4, 2. doi: 10.4172/2329-955x.1000137

Jansen, M. A. K., and Bornman, J. F. (2012). UV-B radiation: from generic stressor to specific regulator. Physiol. Plant. 145, 501-504. doi: 10.1111/j.13993054.2012.01656.x

Kapoor, D., Sharma, R., Handa, N., Kaur, H., Rattan, A., Yadav, P., et al. (2015). Redox Homeostasis in Plants under Abiotic Stress: role of electron carriers, energy metabolism mediators and proteinaceous thiols. Front. Environ. Sci. 3:13. doi: $10.3389 /$ fenvs.2015.00013

Karpets, Y. V., Kolupaev, Y. E., and Vayner, A. A. (2015). Functional interaction between nitric oxide and hydrogen peroxide during formation of wheat seedling induced heat resistance. Russ. J. Plant Physiol. 62, 65-70. doi: $10.1134 /$ S1021443714060090

Kaur, G., Singh, H. P., Batish, D. R., Mahajan, P., Kohli, R. K., and Rishi, V. (2015). Exogenous nitric oxide (NO) interferes with lead $(\mathrm{Pb})$-induced toxicity by detoxifying reactive oxygen species in hydroponically grown wheat (triticum aestivum) roots. PLoS ONE 10:e0138713. doi: 10.1371/journal.pone.0138713

Kim, Y. J., Lee, Y. H., Lee, H. J., Jung, H., and Hong, J. K. (2015). $\mathrm{H}_{2} \mathrm{O}_{2}$ production and gene expression of antioxidant enzymes in kimchi cabbage (Brassica rapa var. glabra Regel) seedlings regulated by plant development and nitrosative stress-triggered cell death. Plant Biotechnol. Rep. 9, 67-78. doi: 10.1007/s11816-015-0343-x

Kong, D., Ju, C., Parihar, A., Kim, S., Cho, D., and Kwak, J. M. (2015). Arabidopsis glutamate receptor homolog3.5 modulates cytosolic $\mathrm{Ca}^{2+}$ level to counteract effect of abscisic acid in seed germination. Plant Physiol. 167, 1630-1642. doi: 10.1104/pp.114.251298

Kovacs, I., Durner, J., and Lindermayr, C. (2015). Crosstalk between nitric oxide and glutathione is required for NONEXPRESSOR OF PATHOGENESISRELATED GENES 1 (NPR1)-dependent defense signaling in Arabidopsis thaliana. New Phytol. 208, 860-872. doi: 10.1111/nph.13502

Krifka, S., Hiller, K. A., Spagnuolo, G., Jewett, A., Schmalz, G., and Schweikl, H. (2012). The influence of glutathione on redox regulation by antioxidant proteins and apoptosis in macrophages exposed to 2hydroxyethyl methacrylate (HEMA). Biomaterials 33, 5177-5186. doi: 10.1016/j.biomaterials.2012.04.013

Lang, T., Sun, H. M., Li, N. Y., Lu, Y. J., Shen, Z. D., Jing, X. S., et al. (2014). Multiple signaling networks of extracellular ATP, hydrogen peroxide, calcium, and nitric oxide in the mediation of root ion fluxes in secretor and non-secretor mangroves under salt stress. Aquat. Bot. 119, 33-43. doi: 10.1016/j.aquabot.2014.06.009

Li, J., Wang, X., Zhang, Y., Jia, H., and Bi, Y. (2011). cGMP regulates hydrogen peroxide accumulation in calcium-dependent salt resistance pathway in Arabidopsis thaliana roots. Planta 234, 709-722. doi: 10.1007/s00425-0111439-3

Li, J. H., Liu, Y. Q., Lü, P., Lin, H. F., Bai, Y., Wang, X. C., et al. (2009). A signaling pathway linking nitric oxide production to heterotrimeric $G$ protein and hydrogen peroxide regulates extracellular calmodulin induction of stomatal closure in Arabidopsis. Plant Physiol. 150, 114-124. doi: 10.1104/pp.109.137067

Li, P., Zhao, C., Zhang, Y., Wang, X., Wang, X., Wang, J., et al. (2016). Calcium alleviates cadmium-induced inhibition on root growth by maintaining auxin homeostasis in Arabidopsis seedlings. Protoplasma 253, 185-200. doi: 10.1007/ s00709-015-0810-9 
Li, S. W., and Xue, L. G. (2010). The interaction between $\mathrm{H}_{2} \mathrm{O}_{2}$ and $\mathrm{NO}, \mathrm{Ca}^{2+}$, cGMP, and MAPKs during adventitious rooting in mung bean seedlings. In Vitro Cell Dev. Biol. 46, 142-148. doi: 10.1007/s11627-009-9275-x

Li, Z. G., Luo, L. J., and Sun, Y. F. (2015). Signal crosstalk between nitric oxide and hydrogen sulfide may be involved in hydrogen peroxide -induced thermotolerance in maize seedlings. Russ. J. Plant Physiol. 62, 507-514. doi: $10.1134 /$ S 1021443715030127

Liao, W. B., Huang, G. B., Yu., J. H., Zhang, M. L., and Shi, X. L. (2011). Nitric oxide and hydrogen peroxide are involved in indole-3-butyric acid-induced adventitious root development in marigold. J. Hortic. Sci. Biotech. 86, 159-165. doi: 10.1080/14620316.2011.11512742

Liao, W. B., Xiao, H. L., and Zhang, M. L. (2009). Role and relationship of nitric oxide and hydrogen peroxide in adventitious root development of marigold. Acta Physiol. Plant. 31, 1279-1289. doi: 10.1007/s11738-009-0367-3

Liao, W. B., Xiao, H. L., and Zhang, M. L. (2010). Effect of nitric oxide and hydrogen peroxide on adventitious root development from cuttings of groundcover chrysanthemum and associated biochemical changes. J. Plant Growth Regul. 29, 338-348. doi: 10.1007/s00344-010-9140-5

Liao, W. B., Zhang, M. L., and Yu, J. H. (2013). Role of nitric oxide in delaying senescence of cut rose flowers and its interaction with ethylene. Sci. Horticult. 155, 30-38. doi: 10.1016/j.scienta.2013.03.005

Liao, W. B., Zhang, M. L., Huang, G. B., and Yu, J. H. (2012a). $\mathrm{Ca}^{2+}$ and $\mathrm{CaM}$ are involved in NO-and $\mathrm{H}_{2} \mathrm{O}_{2}$-induced adventitious root development in marigold. J. Plant Growth Regul. 31, 253-264. doi: 10.1007/s00344-011-9235-7

Liao, W. B., Zhang, M. L., Huang, G. B., and Yu, J. H. (2012b). Hydrogen peroxide in the vase solution increases vase life and keeping quality of cut Oriental $\times$ Trumpet hybrid lily 'Manissa'. Sci. Horticult. 139, 32-38. doi: 10.1016/j.scienta.2012.02.040

Lin, A. H., Wang, Y. Q., Tang, J. Y., Xue, P., Li, C. L., Liu, L. C., et al. (2012). Nitric oxide and protein S-Nitrosylation are integral to hydrogen peroxide-induced leaf cell death in Rice. Plant Physiol. 158, 451-464. doi: 10.1104/pp.111.184531

Liu, J., Macarisin, D., Wisniewski, M., Sui, Y., By, S., Norelli, J., et al. (2013). Production of hydrogen peroxide and expression of ros-generating genes in peach flower petals in response to host and non-host fungal pathogens. Plant Pathol. 62, 820-828. doi: 10.1111/j.1365-3059.2012.02683.x

Liu, W., Li, R. J., Han, T. T., Cai, W., Fu, Z. W., and Lu, Y. T. (2015). Salt stress reduces root meristem size by nitric oxide-mediated modulation of auxin accumulation and signaling in Arabidopsis. Plant Physiol. 168, 343-356. doi: $10.1104 /$ pp. 15.00030

Liu, W. W., Chen, H. B., Lu, X. Y., Rahman, M. J., Zhong, S., and Zhou, B. Y. (2015). Identification of nitric oxide responsive genes in the floral buds of Litchi chinensis. Biol. Plant. 59, 115-122. doi: 10.1007/s10535-014-0466-x

Lu, S., Su, W., Li, H., and Guo, Z. (2009). Abscisic acid improves drought tolerance of triploid bermudagrass and involves $\mathrm{H}_{2} \mathrm{O}_{2}$-and NO-induced antioxidant enzyme activities. Plant Physiol. Biochem. 47, 132-138. doi: 10.1016/j.plaphy.2008.10.006

Lu, Y., Li, N., Sun, J., Hou, P., Jing, X., Zhu, H., et al. (2013). Exogenous hydrogen peroxide, nitric oxide and calcium mediate root ion fluxes in two non-secretor mangrove species subjected to $\mathrm{NaCl}$ stress. Tree Physiol. 33, 81-95. doi: 10.1093/treephys/tps119

Ma, F., Wang, L. J., Li, J. L., Samma, M. K., Xie, Y. J., Wang, R., et al. (2014). Interaction between $\mathrm{HY} 1$ and $\mathrm{H}_{2} \mathrm{O}_{2}$ in auxin-induced lateral root formation in Arabidopsis. Plant Mol. Biol. 85, 49-61. doi: 10.1007/s11103-013-0168-3

Ma, F. F., Lu, R., Liu, H. Y., Shi, B., Zhang, J. H., Tan, M. P., et al. (2012). Nitric oxide-activated calcium/calmodulin-dependent protein kinase regulates the abscisic acid-induced antioxidant defence in maize. J. Exp. Bot. 63, 4835-4847. doi: $10.1093 / \mathrm{jxb} / \mathrm{ers} 161$

Mayer, B., and Hemmens, B. (1998). Biosynthesis and action of nitric oxide in mammalian cells. Trends Biochem. Sci. 22, 477-481. doi: 10.1016/S09680004(97)01147-X

Mehler, A. H. (1951). Studies on reactions of illuminated chloroplasts. II. Stimulation and inhibition of the reaction with molecular oxygen. Arch. Biochem. Biophys.33, 339-351. doi: 10.1016/0003-9861(51) 90082-3

Mittler, R. (2002). Oxidative stress, antioxidants and stress tolerance. Trends Plant Sci. 7, 405-410. doi: 10.1016/S1360-1385(02)02312-9

Mohamed, H. E., Hemeida, A. E., and Mohamed, A. G. (2015). Role of hydrogen peroxide pretreatment on developing antioxidant capacity in the leaves of tomato plant (Lycopersicon esculentum) grown under saline stress. Int. J. Adv. Res. 3, 878-879.

Nathan, C. F., and Hibbs, J. B. (1991). Role of nitric oxide synthesis in macrophage antimicrobial activity. Curr. Opin. Immunol. 3, 65-70. doi: 10.1016/09527915(91)90079-G

Navrot, N., Rouhier, N., Gelhaye, E., and Jacquot, J. P. (2007). Reactive oxygen species generation and antioxidant systems in plant mitochondria. Physiol. Plant. 129, 185-195. doi: 10.1111/j.1399-3054.2006.00777.x

Noelia, F., Mayta, M. L., Lodeyro, A. F., Denise, S., Natalia, C., Carlos, G., et al. (2015). Expression of the tetrahydrofolate-dependent nitric oxide synthase from the green alga ostreococcus tauri increases tolerance to abiotic stresses and influences stomatal development in Arabidopsis. Plant J. 82, 806-821. doi: $10.1111 /$ tpj. 12852

Nyathi, Y., and Baker, A. (2006). Plant peroxisomes as a source of signaling molecules. Biochim. Biophys. Acta 1763, 1478-1495. doi: 10.1016/j.bbamcr.2006.08.031

Oksanen, E., Häikiö, E., Sober, J., and Karnosky, D. F. (2004). Ozone-induced $\mathrm{H}_{2} \mathrm{O}_{2}$ accumulation in field-grown aspen and birch is linked to foliar ultrastructure and peroxisomal activity. New Phytol. 161, 791-799. doi: 10.1111/j.1469-8137.2003.00981.x

Orabi, S. A., Dawood, M. G., and Salman, S. R. (2015). Comparative study between the physiological role of hydrogen peroxide and salicylic acid in alleviating the harmful effect of low temperature on tomato plants grown under sand-ponic culture. Sci. Agric. 9, 49-59. doi: 10.15 192/PSCP.SA.2015.1.9.4959

Pászty, K., Caride, A. J., Bajzer, Ž., Offord, C. P., Padányi, R., Hegedûs, L., et al. (2015). Plasma membrane $\mathrm{Ca}^{2+}$-ATPases can shape the pattern of $\mathrm{Ca}^{2+}$ transients induced by store-operated $\mathrm{Ca}^{2+}$ entry. Sci. Signal. 8, 1-32. doi: 10.1126/scisignal.2005672

Qiao, B., Zhang, Q., Liu, D., Wang, H., Yin, J., Wang, R., et al. (2015). A calcium-binding protein, rice annexin OsANN1, enhances heat stress tolerance by modulating the production of $\mathrm{H}_{2} \mathrm{O}_{2}$. J. Exp. Bot. 66, 5853-5866. doi: $10.1093 /$ jxb/erv294

Rasul, S., Dubreuil-Maurizi, C., Lamotte, O., Koen, E., Poinssot, B., Alcaraz, G., et al. (2012). Nitric oxide production mediates oligogalacturonide-triggered immunity and resistance to botrytis cinerea in Arabidopsis thaliana. Plant Cell Environ. 35, 1483-1499. doi: 10.1111/j.1365-3040.2012.02505.x

Remans, T., Opdenakker, K., Smeets, K., Mathijsen, D., Vangronsveld, J., and Cuypers, A. (2010). Metal-specific and NADPH oxidase dependent changes in lipoxygenase and NADPH oxidase gene expression in Arabidopsis thaliana exposed to cadmium or excess copper. Funct. Plant Biol. 37, 532-544. doi: 10.1071/FP09194

Richards, S. L., Laohavisit, A., Mortimer, J. C., Shabala, L., Swarbreck, S. M., Shabala, S., et al. (2014). Annexin 1 regulates the $\mathrm{H}_{2} \mathrm{O}_{2}$-induced calcium signature in Arabidopsis thaliana roots. Plant J. 77, 136-145. doi: $10.1111 /$ tpj. 12372

Rockel, P., Strube, F., Rockel, A., Wildt, J., and Kaiser, W. M. (2002). Regulation of nitric oxide $(\mathrm{NO})$ production by plant nitrate reductase in vivo and in vitro. J. Exp. Bot. 53, 103-110. doi: 10.1093/jexbot/53.366.103

Sathiyaraj, G., Srinivasan, S., Kim, Y. J., Lee, O. R., Parvin, S., Balusamy, S. R. D., et al. (2014). Acclimation of hydrogen peroxide enhances salt tolerance by activating defense-related proteins in Panax ginseng C.A. Meyer. Mol. Biol. Rep. 41, 3761-3771. doi: 10.1007/s11033-014-3241-3

Serrano, I., Romero-Puertas, M. C., Rodríguez-Serrano, M., Sandalio, L. M., and Olmedilla, A. (2012). Peroxynitrite mediates programmed cell death both in papillar cells and in self-incompatible pollen in the olive (Olea europaea L.). J. Exp. Bot. 63, 1479-1493. doi: 10.1093/jxb/err392

Serrano, M. L., Luque, M. E., and Sánchez, S. S. (2015). Xepac protein and $\mathrm{IP}_{3} / \mathrm{Ca}^{2+}$ pathway implication during Xenopus laevis vitellogenesis. Zygote 23, 99-110. doi: 10.1017/S0967199413000324

Seybold, H., Trempel, F., Ranf, S., Scheel, D., Romeis, T., and Lee, J. (2014). $\mathrm{Ca}^{2+}$ signalling in plant immune response: from pattern recognition receptors to $\mathrm{Ca}^{2+}$ decoding mechanisms. New Phytol. 204, 782-790. doi: 10.1111/nph.13031

Shan, C., Yan, Z., and Liu, M. (2015). Nitric oxide participates in the regulation of the ascorbate-glutathione cycle by exogenous jasmonic acid in the leaves of wheat seedlings under drought stress. Protoplasma 252, 1397-1405. doi: 10.1007/s00709-015-0756-y

Shi, C., Qi, C., Ren, H. Y., Huang, A. X., Hei, S. M., and She, X. P. (2015). Ethylene mediates brassinosteroid-induced stomatal closure via $\mathrm{G} \alpha$ protein-activated 
hydrogen peroxide and nitric oxide production in Arabidopsis. Plant J. 82, 280-301. doi: $10.1111 /$ tpj. 12815

Shi, K., Li, X., Zhang, H., Zhang, G., Liu, Y., Zhou, Y., et al. (2015). Guard cell hydrogen peroxide and nitric oxide mediate elevated $\mathrm{CO}_{2}$-induced stomatal movement in tomato. New Phytol.208, 342-353. doi: 10.1111/nph.13621

Shi, Y., Liu, J., Xin, N., Gu, R., Qin Zhu, L., Zhang, C., et al. (2015). Signals induced by exogenous nitric oxide and their role in controlling brown rot disease caused by monilinia fructicola in postharvest peach fruit. J. Gen. Plant Pathol. 81, 68-76. doi: 10.1007/s10327-014-0562-y

Shoresh, M., Spivak, M., and Bernstein, N. (2011). Involvement of calciummediated effects on ROS metabolism in the regulation of growth improvement under salinity. Free Radic. Biol. Med. 51, 1221-1234. doi: 10.1016/j.freeradbiomed.2011.03.036

Skiba, U., Smith, K. A., and Fowler, D. (1993). Nitrification and denitrification as sources of nitric oxide and nitrous oxide in a sandy loam soil. Soil Biol. Biochem. 25, 1527-1536. doi: 10.1016/0038-0717(93)90007-X

Stöhr, C., Strube, F., Marx, G., Ullrich, W. R., and Rockel, P. (2001).A plasma membrane-bound enzyme of tobacco roots catalyses the formation of nitric oxide from nitrite. Planta 212, 835-841. doi: 10.1007/s004250000447

Tan, J., Wang, C., Xiang, B., Han, R., and Guo, Z. (2013). Hydrogen peroxide and nitric oxide mediated cold- and dehydration-induced myo-inositol phosphate synthase that confers multiple resistances to abiotic stresses. Plant Cell Environ. 36, 288-299. doi: 10.1111/j.1365-3040.2012.02573.x

Tang, R. J., Zhao, F. G., Garcia, V. J., Kleist, T. J., Yang, L., Zhang, H. X., et al. (2015). Tonoplast CBL-CIPK calcium signaling network regulates magnesium homeostasis in Arabidopsis. Proc. Natl. Acad. Sci. U.S.A. 112, 3134-3139. doi: 10.1073/pnas. 1420944112

Tanou, G., Job, C., Belghazi, M., Molassiotis, A., Diamantidis, G., and Job, D. (2010). Proteomic signatures uncover hydrogen peroxide and nitric oxide cross-talk signaling network in citrus plants. J. Proteome Res. 9, 5994-6006. doi: 10.1021/pr100782h

Tanou, G., Job, C., Rajjou, L., Arc, E., Belghazi, M., Diamantidis, G., et al. (2009). Proteomics reveals the overlapping roles of hydrogen peroxide and nitric oxide in the acclimation of citrus plants to salinity. Plant J. 60, 795-804. doi: 10.1111/j.1365-313X.2009.04000.x

Tepe, H. D., and Aydemir, T. (2015). Protective effects of $\mathrm{Ca}^{2+}$ against $\mathrm{NaCl}$ induced salt stress in two lentil (Lens culinaris) cultivars. Afr. J. Agr. Res. 10, 2389-2398. doi: 10.5897/AJAR2014.9479

Tossi, V., Lamattina, L., Jenkins, G. I., and Cassia, R. O. (2014). Ultraviolet-Binduced stomatal closure in Arabidopsis is regulated by the UV RESISTANCE LOCUS8 photoreceptor in a nitric oxide-dependent mechanism. Plant Physiol.164, 2220-2230. doi: 10.1104/pp.113.231753

Urao, T., Katagiri, T., Mizoguchi, T., Yamaguchi-Shinozaki, K., Hayashida, N., and Shinozaki, K. (1994). Two genes that encode $\mathrm{Ca}^{2+}$-dependent protein kinases are induced by drought and high-salt stresses in Arabidopsis thaliana. Mol. Gen. Genet. 244, 331-340. doi: 10.1007/BF00286684

Vandelle, E., Poinssot, B., Wendehenne, D., Bentejac, M., and Alain, P. (2006). Integrated signaling network involving calcium, nitric oxide, and active oxygen species but not mitogen-activated protein kinases in BcPG1-elicited grapevine defenses. Mol. Plant Microbe Interact. 19, 429-440. doi: 10.1094/MPMI-190429

Vavilala, S. L., Gawde, K. K., Sinha, M., and D'Souza, J. S. (2015). Programmed cell death is induced by hydrogen peroxide but not by excessive ionic stress of sodium chloride in the unicellular green alga Chlamydomonas reinhardtii. Eur. J. Phycol. 50, 422-438. doi: 10.1080/09670262.2015.1070437

Wagner, S., Behera, S., De Bortoli, S., Logan, D. C., Fuchs, P., Carraretto, L., et al. (2015). The EF-Hand $\mathrm{Ca}^{2+}$ binding protein MICU choreographs mitochondrial $\mathrm{Ca}^{2+}$ dynamics in Arabidopsis. Plant Cell 27, 3190-3212. doi: 10.1105/tpc.15.00509

Wang, L., Guo, Y., Jia, L., Chu, H., Zhou, S., Chen, K., et al. (2014). Hydrogen peroxide acts upstream of nitric oxide in the heat shock pathway in Arabidopsis seedlings. Plant Physiol. 164, 2184-2196. doi: 10.1104/pp.113.229369

Wang, P., Zhu, J. K., and Lang, Z. (2015). Nitric oxide suppresses the inhibitory effect of abscisic acid on seed germination by s-nitrosylation of snrk2 proteins. Plant Signal. Behav. 10:e1031939. doi: 10.1080/15592324.2015.1031939
Wang, W. H., Yi, X. Q., Han, A. D., Liu, T. W., Chen, J., Wu, F. H., et al. (2011). Calcium-sensing receptor regulates stomatal closure through hydrogen peroxide and nitric oxide in response to extracellular calcium in Arabidopsis. J. Exp. Bot. 63, 177-190. doi: 10.1093/jxb/err259

Wang, Y., Chen, T., Zhang, C., Hao, H., Liu, P., Zheng, M., et al. (2009). Nitric oxide modulates the influx of extracellular $\mathrm{Ca}^{2+}$ and actin filament organization during cell wall construction in pinus bungeana pollen tubes. New Phytol. 182, 851-862. doi: 10.1111/j.1469-8137.2009.02820.x

Wang, Y., Zhang, J., Li, J. L., and Ma, X. R. (2014). Exogenous hydrogen peroxide enhanced the thermotolerance of Festuca arundinacea and Lolium perenne by increasing the antioxidative capacity. Acta Physiol. Plant 36, 2915-2924. doi: 10.1007/s11738-014-1661-2

Wen, J. F., Gong, M., Liu, Y., Hu, J. L., and Deng, M. H. (2013). Effect of hydrogen peroxide on growth and activity of some enzymes involved in proline metabolism of sweet corn seedlings under copper stress. Sci. Horticult. 164, 366-371. doi: 10.1016/j.scienta.2013.09.031

Willekens, H., Chamnongpol, S., Davey, M., Schraudner, M., Langebartels, C., Van Montagu, M., et al. (1997). Catalase is a sink for $\mathrm{H}_{2} \mathrm{O}_{2}$ and is indispensable for stress defence in $\mathrm{C}_{3}$ plants. $E M B O$. J. 16, 4806-4816. doi: 10.1093/emboj/16.16.4806

Wu, A. P., Gong, L., Chen, X., and Wang, J. X. (2014). Interactions between nitric oxide, gibberellic acid, and phosphorus regulate primary root growth in Arabidopsis. Biol. Plant. 58, 335-340. doi: 10.1007/s10535-014-0408-7.

Wu, D., Chu, H. Y., Jia, L. X., Chen, K. M., and Zhao, L. Q. (2015). A feedback inhibition between nitric oxide and hydrogen peroxide in the heat shock pathway in arabidopsis seedlings. Plant Growth Regul. 75, 503-509. doi: 10.1007/s10725-014-0014-x

Wu, J., Shang, Z., Wu, J., Jiang, X., Moschou, P. N., Sun, W., et al. (2010). Spermidine oxidase-derived $\mathrm{H}_{2} \mathrm{O}_{2}$ regulates pollen plasma membrane hyperpolarization-activated $\mathrm{Ca}^{2+}$-permeable channels and pollen tube growth. Plant J. 63, 1042-1053. doi: 10.1111/j.1365-313X.2010.04301.x

Xiang, Z., Jin, W., Jing, Y., Wang, X. L., Zhao, Q. P., Kong, P. T., et al. (2015). Nitric oxide-associated protein1 (atnoa1) is essential for salicylic acidinduced root waving in Arabidopsis thaliana. New Phytol. 207, 211-224. doi: $10.1111 /$ nph.13327

Yu, Y., Yang, Z., Guo, K., Li, Z., Zhou, H., Wei, Y., et al. (2015). Oxidative damage induced by heat stress could be relieved by nitric oxide in trichoderma harzianum LTR-2. Curr. Microbiol. 70, 618-622. doi: 10.1007/s00284-0140764-8

Zhang, H., Wang, W., Yin, H., Zhao, X., and Du, Y. (2012). Oligochitosan induces programmed cell death in tobacco suspension cells. Carbohyd. Polym. 87, 2270-2278. doi: 10.1016/j.carbpol.2011.10.059

Zhang, F., Wang, Y., Yang, Y., Wu, H., Wang, D., and Liu, J. (2007). Involvement of hydrogen peroxide and nitric oxide in salt resistance in the calluses from Populus euphratica. Plant Cell Environ. 30, 775-785. doi: 10.1111/j.1365-3040. 2007.01667.x

Zhou, L., Lan, W., Jiang, Y., Fang, W., and Luan, S. (2014). A calcium-dependent protein kinase interacts with and activates a calcium channel to regulate pollen tube growth. Mol. Plant 7, 369-376. doi: $10.1093 / \mathrm{mp} / \mathrm{sst} 125$

Zou, J. J., Li, X. D., Ratnasekera, D., Wang, C., Liu, W. X., Song, L. F., et al. (2015). Arabidopsis Calcium-Dependent Protein Kinse8 and Catalase 3 function in Abscisic Acid-mediated signaling and $\mathrm{H}_{2} \mathrm{O}_{2}$ homeostasis in stomatal guard cells under drought stress. Plant Cell 27, 1445-1460. doi: 10.1105/tpc. 15.00144

Conflict of Interest Statement: The authors declare that the research was conducted in the absence of any commercial or financial relationships that could be construed as a potential conflict of interest.

Copyright ( $\odot 2016 \mathrm{Niu}$ and Liao. This is an open-access article distributed under the terms of the Creative Commons Attribution License (CC BY). The use, distribution or reproduction in other forums is permitted, provided the original author(s) or licensor are credited and that the original publication in this journal is cited, in accordance with accepted academic practice. No use, distribution or reproduction is permitted which does not comply with these terms. 